RADOVI

Zavoda za znanstveni rad HAZU Varaždin

ANA KANIŠKI

Varaždin

ana.kaniski@gmail.com
UDK 748.5:262.2(497.523 Varaždinske Toplice)

Pregledni članak

Review

\title{
VITRAJI PAVLA VOJKOVIĆA U ŽUPNOJ CRKVI SV.MARTINA BISKUPA U VARAŽDINSKIM TOPLICAMA
}

\begin{abstract}
Autorica u radu obrađuje tri vitraja akademskog slikara, scenografa i kostimografa Pavla Vojkovića (Varaždin, 24. lipnja 1912. - 26. prosinca 2006.) koje je ovaj varaždinski umjetnik izradio za svetište župne crkve sv. Martina biskupa u Varaždinskim Toplicama. Dva vitraja s prikazom dva najznačajnija događaja iz svečeva života, Sv. Martin i prosjak $i$ Sv. Martin biskup, te vitraj s prikazom tetramorfa, postavljeni su 1983. godine. Osim podataka o ikonografiji vitrajā, godini postavljanja i autoru nacrta, župna spomenica bilježi i podatak o njihovom izrađivaču, poduzeću »Staklo«iz Zagreba. Sačuvano je devet skica za izradu tih vitraja koje je Pavle Vojković izradio tijekom 1982. i 1983. godine, a dio su Zbirke Pavla Vojkovića Gradskoga muzeja Varaždin i slikareve ostavštine u privatnom vlasništvu. Pripadaju pozamašnome sakralnom opusu Pavla Vojkovića koji dosad još nije bio u potpunosti obradivan. Usporedba skica s izvedenim vitrajima pokazuje da je slikar na skicama mijenjao idejna rješenja vitrajā - ikonografski $i$ kompozicijski. Autorica tumači te vitraje u okviru ikonografije svetišta za koji su oni i izvorno izrađeni i u okviru cjelokupnoga slikarevoga slikarskog opusa. Zaključuje da uz sliku Sv. Martin i prosjak, koja je stajala na glavnom oltaru, vitraji jedini nose ikonografiju titulara župne crkve u Varaždinskim Toplicama, da su među prvim djelima suvremene likovne umjetnosti u župnoj crkvi, te da stilski pripadaju trima različitim sukcesionim slikarskim fazama Pavla Vojkovića, od početka 1960-ih do kraja 1980-ih godina.
\end{abstract}

O umjetniku Pavlu Vojkoviću (Varaždin, 24. lipnja 1912. - 26. prosinca 2006.) dosada se pisalo u okviru njegovoga slikarskoga, scenografskoga i kostimografskoga rada. Varaždinski tjedni list Varaždinske novine nebrojenim su novinskim člancima pratile njegov rad još od sredine 1940-ih godina, a osvrtale su se i na njega poslije umjetnikove smrti. Međutim, najobuhvatniji uvid u svestrano stvaralaštvo Pavle Vojkovića dosada je dala Mirjana Dučakijević, dvama katalozima koji su popratili 
umjetnikove retrospektivne izložbe održane u Gradskome muzeju Varaždinu. Prva je održana 1991. godine za njegova života, a druga nekoliko godina poslije njegove smrti, povodom stogodišnjice njegova rođenja 2012. godine. ${ }^{1} \mathrm{U}$ drugome je katalogu izložbe Mirjana Dučakijević pokazala slikarski, kiparski i scenografski Vojkovićev opus, uz koji je uključila i popis sakralnoga opusa i popratila ga fotografijama odabranih radova. ${ }^{2}$ Iako stavljen uz njegov svestrani rad, Vojkovićev sakralni opus dosada nije bio posebno obrađivan.

\section{UVOD}

Godine 1983. svetište župne crkve sv. Martina biskupa u Varaždinskim Toplicama dobiva tri vitraja koje je prema skicama Pavla Vojkovića izradilo poduzeće "Staklo« iz Zagreba. ${ }^{3}$ Njegovi su šiljato zaključeni pravokutni gotički otvori bili ostakljeni vitrajima koji nose najznačajnije ikonografske prizore iz života titulara topličke crkve. Na sjevernome zidu svetišta gotički otvor bliži slavoluku »nosi« vitraj s prikazom tetramorfa, simbola četiriju evanđelista. Njemu zdesna gotički otvor »nosi« vitraj Sv. Martin i prosjak; nasuprot njemu na južnom zidu svetišta postavljen je vitraj s prizorom Sv. Martin biskup. Ti podaci o vitrajima, osim njihova smještaja u svetištu, zabilježeni su u župnoj spomenici Napisnik znamenitijih dogadjajah i proimenah u župi Topličkoj - izvodjen počam od 1. studenoga 1863 godine po Eduardu Peroku upravitelju župe Topličke, na nepaginiranoj stranici ispod niza zapisa za 1983. godinu. ${ }^{4}$ Podatak da su izvedeni prema skicama varaždinskoga umjetnika potvrđuje natpis NACRT / P. VOJKOVIĆ / STAKLO - ZGB / IZVELO, zapisan u donjem desnom kutu vitraja Sv. Martin i biskup. Zabilješku u župnoj spomenici i natpis na vitraju potvrđuju devet sačuvanih skica koje je slikar izradio 1982. i 1983. godine. Usporede li se

1 Pavle Vojković: retrospektiva: 1936.-1991.: Galerija slika Varaždin, 3. 6. - 4. 8. 1991., Varaždin, Gradski muzej Varaždin, 1991.

2 Za slikara vidi: Pavle Vojković [Povodom stote obljetnice rođenja Pavla Vojkovića. Retrospektivna izložba 4. 12. 2012. - 3. 3. 2013.], Gradski muzej Varaždin, Varaždin, 2012. (dalje: Pavle Vojković, 2012.) Uz tekst autorice izložbe, katalog sadrži i kraći tekst Marijana Varjačića Pavle Vojković kao scenograf.

3 O župnoj crkvi vidi: Božena FILIPAN, »Barokna baština Varaždinskih Toplica s osvrtom na zaštitu i revitalizaciju «, Hrvatska akademija znanosti i umjetnosti, Radovi Zavoda za znanstveni rad Varaždin, Varaždin,, br. 8/9, 1996., 41-73.; Tomislav ĐURIĆ, Crkvena baština varaždinsko-topličkog kraja: Posvečeno 70. godišnjici života Tomislava Đurića, Meridijani, Varaždinske Toplice - Samobor, 2009./2010. (dalje: ĐURIĆ, 2009./2010.)

4 »U župnoj crkvi u svetištu postavljena su 3 prozora u vitraj- / tehnici. 1 prozor - simboli evanđelista, 1 prozor sveti Martin i / prosjak, 1 prozor sveti Martin biskup. Nacrte za prozore izradio / je profesor Pavao Vojković iz Varaždina, a radove izvelo poduzeće / 'Staklo' iz Zagreba«. Vidi župnu spomenicu Napisnik znamenitijih dogadjajah i proimenah u župi Topličkoj - izvodjen počam od 1. studenoga 1863 godine po Eduardu Peroku upravitelju župe Topličke, za 1983. godinu, bez paginacije. Za uvid u župnu spomenicu srdačno zahvaljujem župniku Stjepanu Mostečaku. 
s postojećim vitrajima, zaključuje se da je Vojković u dvije godine promijenio kako ikonografska, tako i kompozicijska rješenja prizora triju vitraja. Međutim, potrebno je prvo osvrnuti se na sam pojam vitraja i na ikonografiju sv. Martina biskupa.

\section{OPĆENITO O VITRAJIMA I IKONOGRAFIJI SV. MARTINA}

Prema Likovnom leksikonu [2014.], homonim vitraj označava slikarsku tehniku, i to prema predlošku realiziranu kompoziciju s pomoću raznobojnih staklenih pločića međusobno povezanih s olovnim okvirima (armaturom), te prozor proizveden ovom tehnikom. ${ }^{5}$ Tekstovi u enciklopedijama i likovnim leksikonima, uz nerijetko sličnu sažetu definiciju vitraja daju pregled povijesti njihove izrade, od kasnoantičke do suvremene umjetnosti navodeći promjene u stilu i tehnici izrade. Najstariji sačuvani fragmenti koji se smatraju vitrajem, staklene su pregrade izrađene od ulomaka raznobojnih stakalca umetnutih u mrežište od kamena ili žbuke ili drva, te ploče alabastera u kasnoantičkim bazilikama u Rimu i Raveni. ${ }^{6}$ U IX. stoljeću prvi se puta spominje riječ vitraj, u X. stoljeću pojavljuju prvi traktati o tehnici izrade kada se izrađuju vitraji od teških kamenih ili žbukanih transena ili metalnih mrežišta. Vitraji su izrađivani od obojanoga stakla (gdje je pigment umješan $u$ staklo pri pečenju) ili oslikanoga stakla gdje se pigment (kobalt za plavu i bakar za crvenu boju) nanešen na površinu pričvršćuje pečenjem u peći. ${ }^{7}$ Misli se da su najstariji sačuvani vitraji in situ upravo oni u katedrali u Augsburgu (1050.-1100.). ${ }^{8}$ U vidu tehnike izrade, smatra se da vitraji svoj vrhunac doživljavaju u razdoblju romanike i gotike. Romanički vitraji izrađeni su od olovom povezanih raznobojnih stakalaca koji su umetnuti željeznu armaturu. Najčešće manjih dimenzija, izrađivani su od stakalaca snažne modre, crvene, narančaste i zelene boje. U razdoblju gotike, inovacije poput tehnike izrade željeznih šipki nepravilnoga oblika, upotreba dijamantnih noževa za lakše rezanje stakla, omogućili su izradu vitraja od sitnijih stakalaca nepravilnih oblika u složenijim mrežištima i rozetama; koriste se smeđa i ljubičasta stakla. Iz opatijske crkve St. Denis utjecaji su se ubrzo proširili na Chartres, Poitiers i Angers, potom iz kraljevske kapele Sainte-Chapelle u Englesku (u katedrali u Canteburyju, opatiji u Westminsteru) i u Njemačku (Strassbourg, Triginija,

\footnotetext{
»vitraj«, Likouni leksikon, gl. ur. Josip Bilić, Zagreb, 2014., 1008.

6 »vitrail«, Enciklopedija likovnih umjetnosti: Sv. 4: Portr - Ž, Dodatak, gl. red. Slavko Batušić, Andre Mohorovičić, Mirko Šeper, Zagreb, 1966., 538. (dalje: ELU, 1966.)

7 Usp. razliku u anglosaksonskim terminima: obojano staklo (coloured - dyed in substance) i oslikano staklo (painted - pigments applied to its surface), u: »stained glass", The Oxford Dictionary of Art and Artists, Ian Chilvres, Oxford, 2009., 599. (dalje: CHILVRES, 2009.)

8 CHILVRES, 2009., 599.
} 
Bamberg), te kasnije u Italiju (Sienna, Firenca, Asisi). ${ }^{9} \mathrm{U}$ renesansi se upotrebljavala jeftinija tehnika izrade vitraja: koristili su se emajl ili tanki slojevi boje nanošeni na staklo koji su se nakon pečenja mogli sastrugati s površine. ${ }^{10}$ Ograničenja tehničke naravi i nemogućnost realističkoga prikazivanja značajnoga za renesansu doveli do pada upotrebe i tehnike vitraja. ${ }^{11}$ Dekorativna ornamentika, heraldički motiv i grisaille značajni su za barokne vitraje. Tek će se u razdoblju historicizma obnoviti interes za vitraj, i to preko različitih umjetničkih pokreta, poput engleskoga Arts \& Crafts. U tom će razdoblju vitraj svoje mjesto naći i u svjetovnim, reprezentativnim građevinama. Osim tehničkih dostignuća poput izrade vitraja od debelih komada obojanog stakla povezanog cementom, u secesiji i izmima XX. stoljeća korištene su teme iz ranijih razdoblja.

Višesveščana enciklopedija The New Book Encyclopedia [1994.] uz svoj je povijesni pregled razvoja tehnike vitraja dodala i detaljan opis njihove izrade, od početne ideje do konačne izrade. ${ }^{12}$ Umjetnik počinje izradom skice ili crteža, koji koristi kao model za izradu obrisa vitraja, karton, i to u pravoj veličini vitraja. Na skicama i na kartonu umjetnik određuje oblik i boju svakog stakalca i naznačuje olovne trake. Izrađeni karton precrtava se na teži papir, papir se izrezuje na komade i komadima se označuje njihova boja. Svaki izrezani komad papira prislanja se na staklo odgovarajuće boje, rezačem se naznačuju rubovi komada papira i staklo se potom lomi ili reže. Ukoliko ih skica predviđa, sjenčanje i detalji (poput modelacije lica) izvedu se nanošenjem emajla (smjese smrvljenoga stakla, željeznih oksida, vode ili ulja) na površinu komada stakla koji se potom peku u peći. Svi komadi stakla poslažu se na karton prema naznačenom obliku i boji, te spajaju lako savitljivim trakama olova: stakalce se umeće u utor olovne trake, svaki se utor prilagodi površini stakla, spojevi olovnih traka se zaleme i potom se utori zakitaju kako bi bili vodootporni. Ukoliko se izrađuju vitraji velikih dimenzija, nerijetko se dijele na nekoliko parcela i svaki dio vitraja umeće se u željeznu armaturu koja se onda postavlja u otvor. Željezna armatura se koristi kako bi ojačala vitraj protiv jakoga vjetra i, navodi Ian Chilvres [2009.], kako bi se njime naglasio oblik otvora u koji se umeće. ${ }^{13}$ Imajući na umu ovaj opis, vidljivo je da u izradi vitraja sudjeluju umjetnik i staklar(i), odnosno, vitražist(i). Umjetnik bi svojim skicama morao moći olakšati staklarima izradu vitraja. To čini dodatnim opisom i točnim mjerilom u kojem je skica vitraja rađena, fiksiranjem

\footnotetext{
ELU, 1966., 538.

10 CHILVRES, 2009., 599.

11 "stained glass«, The New Encyclopaedia Britannica. Micropaedia: ready reference. 11, Solovyov-Truck, 15th Edition, ur. Robert Gwinn, Chicago, 1995., 203.

12 »Stained glass«, The World Book Encyclopedia: Volume 18: So-Sz, Chicago, 1994., 821-821.

13 CHILVRES, 2009., 599.
} 
olovnih traka ili armature te kolorističkom skalom za predviđena stakalca od kojih bi se vitraj imao izraditi. Staklar bi morao moći u skladu sa svojim tehničkim znanjem i vještinom prenijeti skiciranu umjetnikovu ideju u konačni ostakljeni proizvod.

U životu sv. Martina biskupa najznačajnija su dva događaja. ${ }^{14}$ Prvi se dogodio $\mathrm{u}$ vrijeme kada je još kao vojnik služio u konjaništvu cara Konstantina Velikog. Jednoga zimskog dana u gradu Amiensu naišao je na »nekoga prosjaka, odjevena u prnje i prozebla od ljute studeni. Martin skinu sa sebe svoj plašt, mačem ga rasiječe napola i polovinu dade siromahu « ${ }^{15}$ Nakon tog čina milosrđa odlučio je napustiti vojsku i svoj život posvetiti redovništvu. Drugi se dogodio netom prije nego je redovnik Martin proglašen biskupom. Saznavši da je imenovan za biskupa u gradu Toursu, ali želeći »nastaviti svoj život u redovničkoj samoći, sakri se pred poslanicima koji dođoše da ga odvedu u Tours. Prema legendi, neka guska svojim gakanjem otkri mu skrovište, i on moradne prihvatiti novu dužnost« « ${ }^{16} \mathrm{U}$ likovnim se umjetnostima uvriježio prikaz sv. Martina u »[...] biskupskoj odori, katkad s guskom kraj sebe ili u rukama. Na ostalim slikama prikazan je na konju u vojničkoj odori kako mačem siječe svoj plašt da njime ogrne prosjaka «. ${ }^{17}$ Upravo takvim ga je na dvama vitrajima u svetištu crkve prikazao i Pavle Vojković - s brojnim razlikama od ideje do realizacije.

\section{SKICE ZA VITRAJ SV. MARTIN I PROSJAK}

Prema sadašnjim saznanjima, sačuvano je sveukupno devet skica za izradu triju vitraja župne crkve sv. Martina u Varaždinskim Toplicama. Tri skice dio su Zbirke Pavla Vojkovića Gradskog muzeja Varaždin, a šest skica dio je umjetnikove ostavštine koja se nalazi u vlasništvu gđe. Dragice Škarice. ${ }^{18}$ Skice su izrađene crnom olovkom, flomasterom u boji i/li akvarelom na okomito položenom papiru, različitih dimenzija. Neki skicirani vitraji dodatno su obrazloženi naslovom, mjerilom, dimenzijama,

14 O ikonografiji sv. Martina biskupa vidi: Louis RÉAU, Iconographie de L'art Chrétien: Iconographie des Saints II: G-O, Presses Universitaires de France, Paris, 1958., 900-917.; »Martin of Tours«, The Oxford Dictionary of Saints, David Hugh Farmer, Oxford, [1978.] 2011., 294-296., Jacobus de VORAGINE, The Golden Legend or Lives of Sints as Englished by William Caxton: Vol. Six, ed. F. S. Ellis, J. M. Dent and Co. i Aladine House, London, 1900., 141-158., te »Martin biskup, sveti«, Leksikon ikonografije liturgike i simbolike zapadnog kršćanstva [IV. dopunjeno izdanje], ur. Anđelko Badurina, Zagreb, 2000., 428-429. (dalje: Leksikon ikonografije, 2000.)

15 Leksikon ikonografije, 2000., 428.

16 Ibidem, 428-429.

17 Ibidem, 429.

18 Autorica ovoga rada najsrdačnije zahvaljuje gđi. Dragici Škarici na ustupanju dviju Vojkovićevih mapa sa sakralnim radovima. Mape sadrže skice vitraja koje se obrađuju u ovom radu, te su i citirane niže $\mathrm{u}$ radu. 
tzv. »ljestvicom obojenog stakla«, a poneki sadrži opasku o njegovom smještaju u svetištu - potrebnim informacijama i umjetnikovim uputama staklarima za izradu vitraja. Većina skica je potpisana P. VOJKOVIĆ ili VP, datirana 82. ili 83. Tri skicirana vitraja svojim dimenzijama i oblikom odgovaraju otvorima zida trostranoga svetišta župne crkve. Stoga ta tri skicirana vitraja imaju oblik uspravnog pravokutnika sa šiljatim zaključkom. Na svakoj skici vitraja umjetnik je olovkom naznačio olovne trake i crnim flomasterom željeznu armaturu vitraja. Upisane dimenzije upućuju na to da vitraji svojom visinom i širinom odgovaraju visini i širini gotičkog otvora (270 x $110 \mathrm{~cm}$ ). Međutim, vitraji su sadržajno podijeljeni na tri dijela: na središnji pravokutni dio koji nosi glavni ikonografski prizor, nad njim lučni dio omeđen šiljatim lukom koji nosi dodatni prizor i na dekorativni »obrub«.

Skica iz 1982. godine naslovljena Vitrail za župnu crkvu Sv. Martin u Varaždinskim Toplicama nosi prikaz vitraja Sv. Martin i prosjak u mjerilu 1:5, koji je slikar predvidio za »prvi prozor u svetištu lijevo« (slika 1.). ${ }^{19}$ Pravokutni dio sadrži prizor mladolikoga i plavokosoga vojnika Martina u raskošnoj plavičastoj vojničkoj odori, kako jašući na konju bijelcu, mačem siječe svoj crvenkasti plašt ne bi li tu polovicu dao žgoljavomu crnokosom prosjaku, odjevenome u smeđe prnje koji ispred njega sjedi na zelenkastoj tratini, prekriženih nogu i dlanova skupljenih u znak zahvale. Bočno izgladnjelome prosjaku koji je svojim koščatim leđima okrenut promatraču, nalaze se žbunje i cvijeće. Iza njih nazire se brdoviti krajolik. Ključni trenutak toga milosrdnog čina i silinu zamaha mačem, Pavle Vojković je vizualno dočarao jednostavnim položajem tijelā prosjaka i vojnika: prvi je blago nagnut udesno, drugi okrenut ulijevo, dajući dojam dijagonale koja ide od donjega lijevog do gornjega desnog kuta središnjeg dijela. Metalni mač i položaj glave bijelca usporedne su osi koje se protežu od gornjega lijevog do donjega desnog kuta središnjega dijela. Osi se vizualno »sjeku« na mjestu gdje mač siječe crvenkasti plašt, istaknut kontrastom bijele dlake i grive bijelca. U lučnome dijelu slikar je predvidio čovjekoliko sunce čijih dvanaest zraka razdjeljuje niz od plavih, zelenih i ljubičastih polja dajući dojam nedefinirane pozadine. Obrub vitraja čine niz plavih, žutih i nekolicine crvenih trokuta. Uz donju polovicu desnoga ruba papira nalazi se »ljestvica obojenog stakla«, numerirana kvadratna polja raznih boja, kao uputa staklarima u pravilnom odabiru obojanoga stakla.

Godinu dana poslije nastala je druga skica za isti vitraj, a na što pokazuje akvarelirana nenaslovljena, signirana i datirana skica izvedena u mjerilu 1:10 (slika 2.). ${ }^{20}$

19 Pavle Vojković, Vitrail za župnu crkvu »Sv. Martin« u Varaždinskim Toplicama, 1982., olovka i flomaster na papiru, 35,3 x 59,3 cm, Gradski muzej Varaždin, inv. br. GMV 65100.

20 Pavle Vojković, Skica za vitraj s prikazom Sv. Martina i prosjaka za Župnu crkvu sv. Martina u Varaždinskim Toplicama, 1983., olovka, flomaster i akvarel na papiru, 35,3 x 59,3 cm, Gradski muzej Varaždin, inv. br. GMV 65099. 
U odnosu na prvotnu skicu, neznatne promjene učinjene su na prikazu iz svečeva života - ne zadirući u prvotnu kompoziciju, mladi plavokosi vojnik postao je crnokosi, potom su uklonjeni cvijeće zdesna prosjakovih nogu i brdoviti krajolik koji je zamijenjen malom utvrdom s dvije kule i zidinama s kruništem - kao aluzija na srednjovjekovne zidine grada Amiensa. Najveće promjene uočavaju se u lučnome dijelu vitraja, gdje je čovjekoliko sunce zamijenjeno Kristom Pantokratorom. Frontalno prikazan odrasli i bradati Krist s crveno-narančastom aureolom, odjeven u plavu halju i ljubičasti plašt, povišenom desnicom blagoslivlja, a u ljevici drži kuglu. Iza je nedefinirana pozadina koju bi trebalo činiti niz plavih stakalaca. Promjene su zadesile i obrub od bjelkastih, crvenih, žutih i plavih stakalca. Ovu skicu prati i slikareva opaska KOMBINIRATI OVU SKICU U BOJI (1:10) SA ONOM VEĆOM (1:5)!. Iste godine slikar je izveo i treću skicu (slika 3.), ${ }^{21}$ koja pokazuje najviše sličnosti s prvotnim idejnim rješenjem glede čovjekolikoga sunca u lučnom dijelu i obruba, ali odstupa u kompoziciji prizora iz svečeva života. Dinamičnu kompoziciju zamijenio je sa statičnom: figurama mladoga bradatog prosjaka i bradatoga vojnika sa šljemom koji stoje međusobno okrenuti jedan prema drugome ispred konja bijelca. Vojnik mačem siječe plašt, a prosjak dlanove drži u znaku molitve. Na toj su skici, odnosno na papiru bočno od skiciranoga vitraja olovkom skicirana tri malena vitraja, jedan iznad drugoga. Gornji i središnji nose prikaz Sv. Martin i prosjak sa statičnim figurama vojnika i prosjaka, ali se razlikuju u oblikovanju lučnoga dijela: prvi sadrži tri malene rozete, drugi jednu rozetu i treći vitraj sadrži prikaz tetramorfa (slika 3a.). Četvrta sačuvana skica tog vitraja pokazuje lučni dio sa čovjekolikim suncem i obrub s dekoracijom kakva je na prethodno opisanoj skici (slika 4). ${ }^{22}$ Međutim, toj četvrtoj pomno izvedenoj skici izrezan je središnji dio, koji je najvjerojatnije sadržavao prikaz stojećih figura vojnika i prosjaka.

Zaključuje se da su u samoj izradi toga vitraja iskombinirana rješenja s prve dvije skice: središnji dio nosi prikaz Sv. Martina i prosjaka koji je uzet s prvog nacrta pri čemu je plavokosome vojniku dana aureola, dok su lučni dio i obrub izvedeni prema drugoj skici (slika 5.). ${ }^{23}$ Promjena se dogodila i u smještaju vitraja. Iako je izvorno bio namijenjen prvome prozoru lijevo u svetištu, postavljen je u bočni, drugi prozor; na njegovo je mjesto postavljen vitraj s prikazom tetramorfa. Ranije spomenuta treća skica za vitraj Sv. Martin i prosjak sadrži rudimentarnu skicu za vitraj sa simboličnim prikazima četi-

21 Pavle Vojković, Skica za vitraj s prikazom Sv. Martina i prosjaka za Župnu crkvu sv. Martina u Varaždinskim Toplicama, 1983., olovka i flomaster na papiru, 25,5 x 35,5 cm. Iz ostavštine u vlasništvu gđe. Dragice Škarice.

22 Pavle Vojković, Za Žup. cr[kvu »Sv. Martina«] Vžd. Toplice, 1982. ili 1983., flomaster na papiru, 23,5 x $29,5 \mathrm{~cm}$. Iz ostavštine gđe. Dragice Škarice.

23 Pavle Vojković, Sv. Martin i prosjak, vitraj, 110 x 270 cm, svetište Župne crkve sv. Martina biskupa, Varaždinske Toplice. 
riju evanđelista. U superponiranom se redu nižu prikazi sv. Marka, Mateja, Luke i Ivana pri čemu najmlađi evanđelist zadire u lučni dio. Obrub vitraja bi trebala činiti načrčkana valovita linija. Konačni vitraj pokazuje razlike u ikonografiji i kompoziciji (slika 6.). ${ }^{24}$ Njegov središnji pravokutni dio podijeljen je na četiri polja, a svaki sadrži stilizirani simbolični prikaz evanđelista između ispisa njegovoga imena i knjige, to jest, evanđelja. Promijenjen im je i raspored: sv. Ivan (ime - krilati orao - evanđelje), sv. Marko (evanđelje - krilati lav - ime), sv. Luka (ime - krilati vol - evanđelje) i sv, Matej (knjiga - krilati čovjek -ime). Lučni dio krasi simbolični prikaz Duha Svetoga u obliku golubice s aureolom, a obrub niz zelenih trokuta i smeđih trokuta s crvenim točkama.

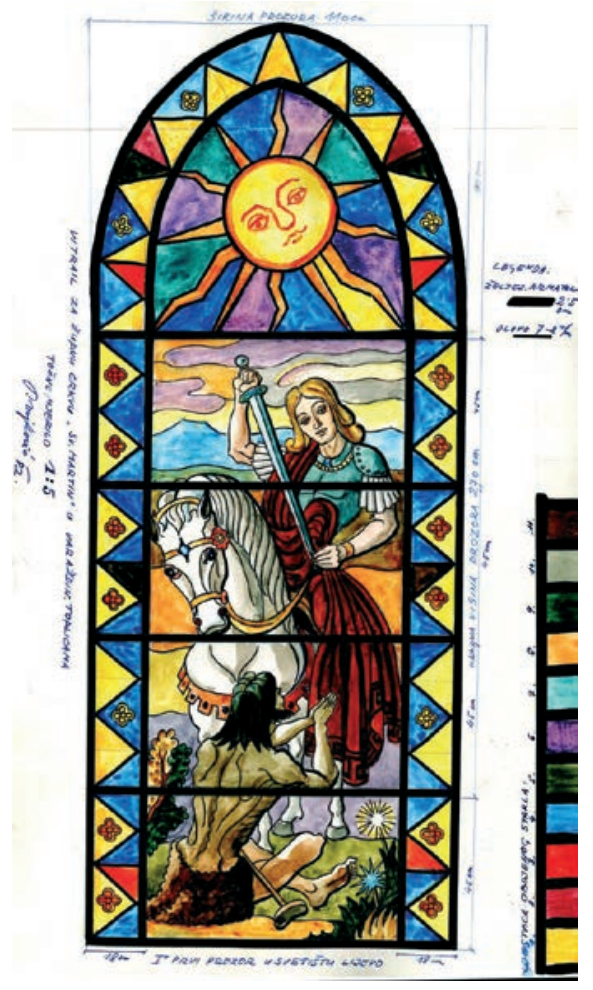

Slika 1. Pavle Vojković, Vitrail za župnu crkvu "Sv. Martin« u Varaždinskim Toplicama, 1982., olovka i flomaster na papiru, 35,3 × 59,3 cm, Gradski muzej Varaždin.

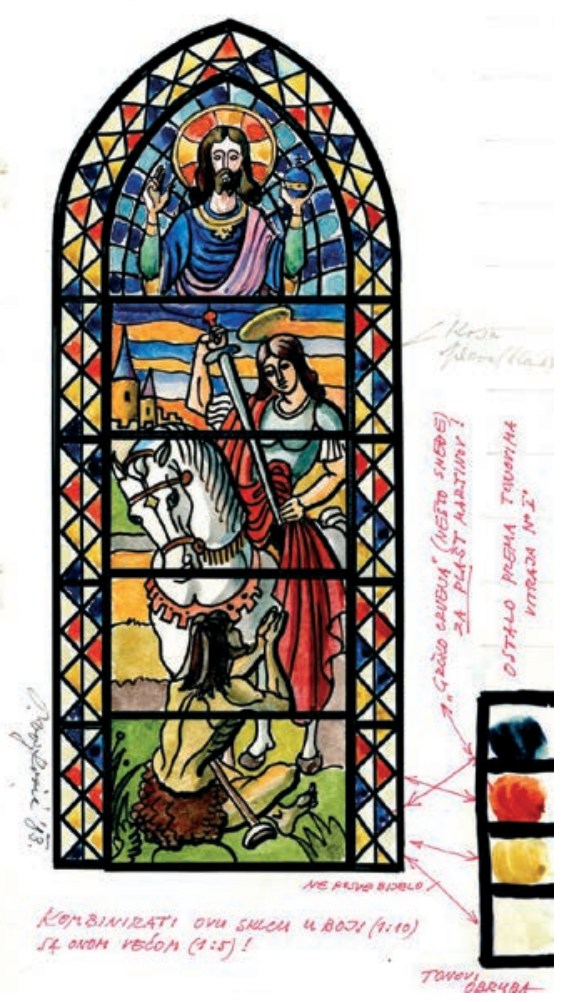

Slika 2. Pavle Vojković, Skica za vitraj s prikazom Sv. Martina i prosjaka za Župnu crkvu sv. Martina u Varaždinskim Toplicama, 1983., olovka, flomaster i akvarel na papiru, 35,3 x 59,3 cm, Gradski muzej Varaždin.

24 Pavle Vojković, Tetramorf, vitraj, 110 x 270 cm, svetište Župne crkve sv. Martina biskupa, Varaždinske Toplice. 


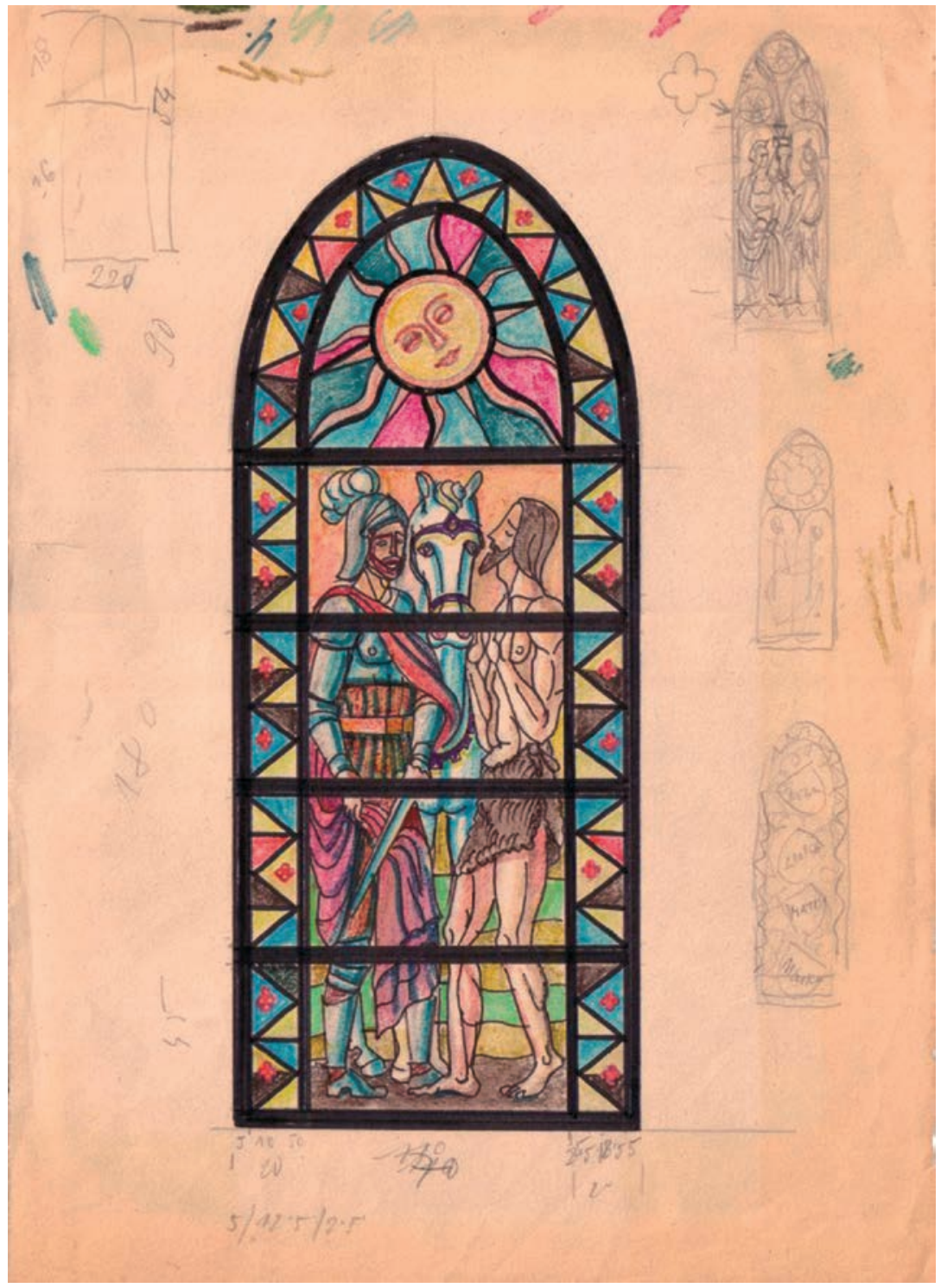

Slika 3. Pavle Vojković, Skica za vitraj s prikazom Sv. Martina i prosjaka za Župnu crkvu sv. Martina u Varaždinskim Toplicama, 1983., olovka i flomaster na papiru, 25,5 × 35,5 cm. Iz slikareve ostavštine u vlasništvu gđe. Dragice Škarice. 


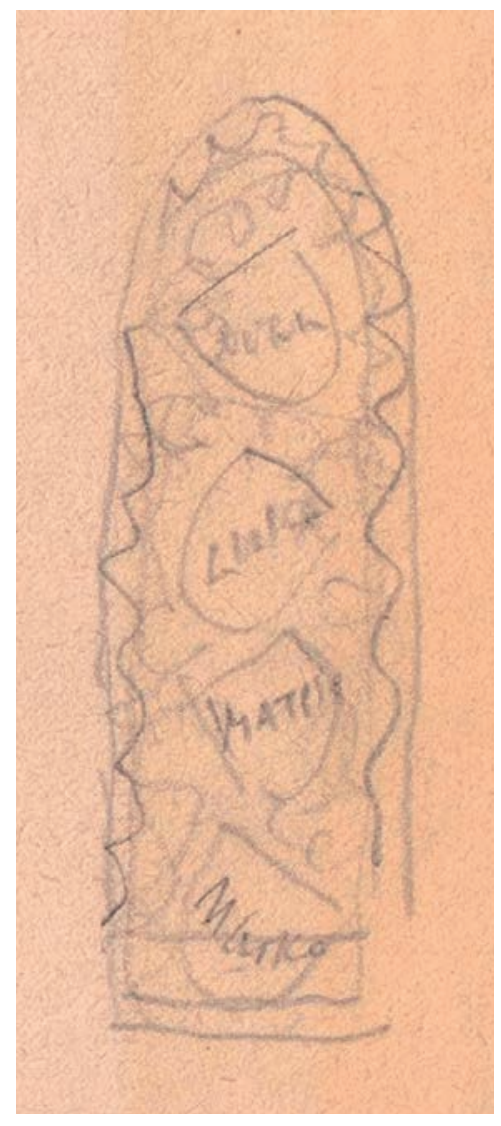

Slika 3a. Pavle Vojković, Detalj skica za vitraj s prikazom Sv. Martina i prosjaka za Župnu crkvu sv. Martina u Varaždinskim Toplicama, 1983., olovka i flomaster na papiru, $25,5 \times 35,5 \mathrm{~cm}$. Iz slikareve ostavštine u vlasništvu gđe. Dragice Škarice.

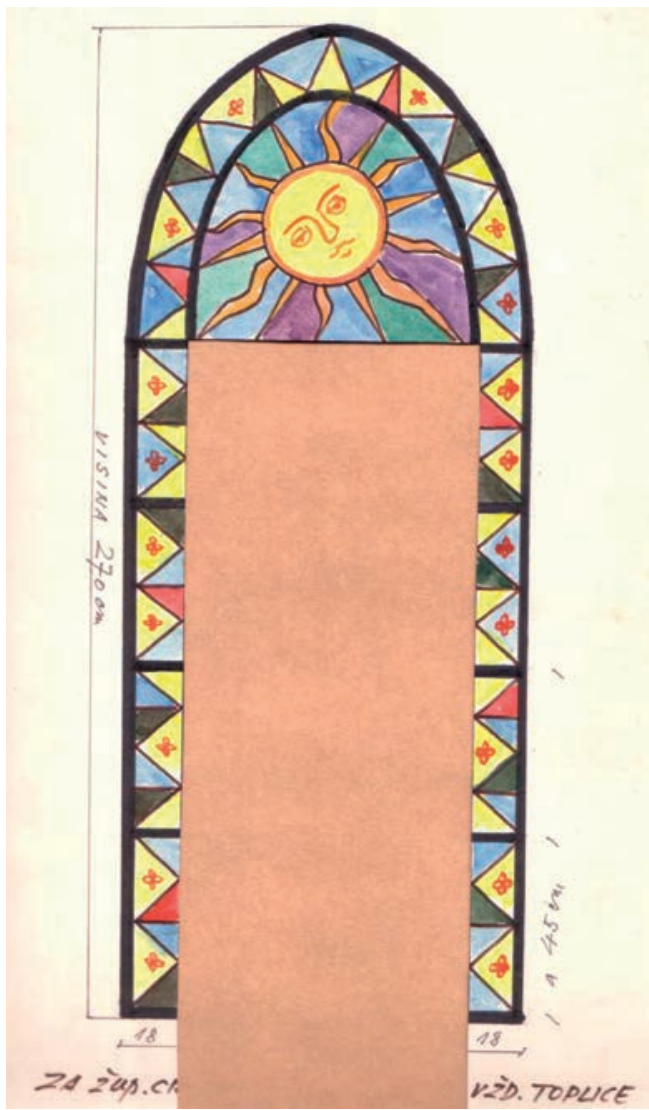

Slika 4. Pavle Vojković, Za Žup. cr[kvu »Sv. Martina»] Vžd. Toplice, 1982. ili 1983., flomaster na papiru, $23,5 \times 29,5 \mathrm{~cm}$. Iz slikareve ostavštine u vlasništvu gđe. Dragice Škarice. 


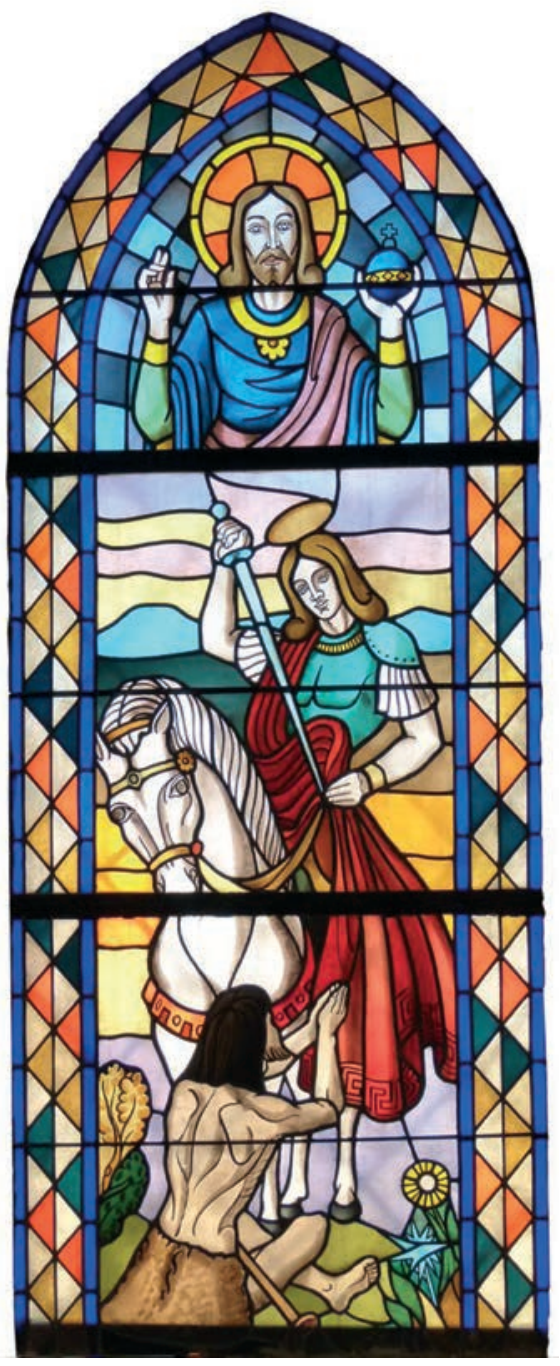

Slika 5. Pavle Vojković, Sv. Martin i prosjak, vitraj, $110 \times 270 \mathrm{~cm}$, svetište Župne crkve sv. Martina biskupa, Varaždinske Toplice. (Fotografiju obradio Ivan Kreč)

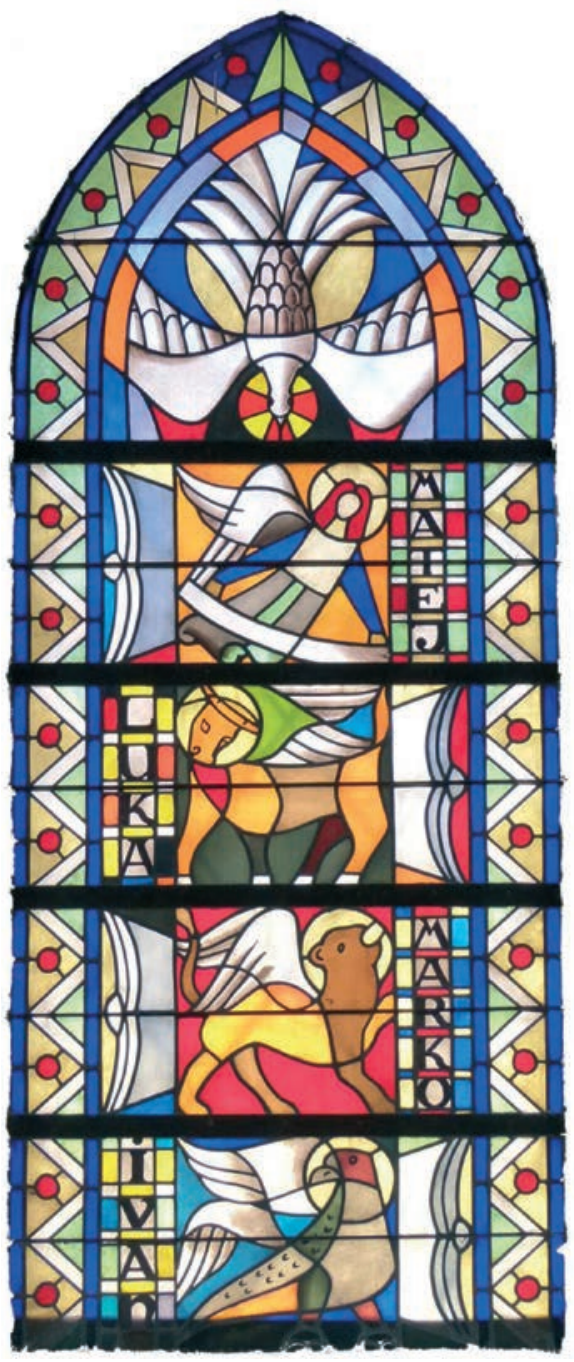

Slika 6. Pavle Vojković, Tetramorf, vitraj, 110 x $270 \mathrm{~cm}$, svetište Župne crkve sv. Martina biskupa, Varaždinske Toplice. (Fotografiju obradio Ivan Kreč) 


\section{SKICE ZA VITRAJ SV. MARTIN BISKUP}

Jedini gotički prozor na južnome zidu svetišta župne crkve ostakljen je s vitrajem Sv. Martin biskup (slika 11.). ${ }^{25} \mathrm{U}$ središnjem pravokutnom dijelu, frontalno je prikazan stojeći lik odrasloga sv. Martina svijetle kose i brade s mitrom na glavi, u bijeloj halji i narančastoj kazuli. Povišenom desnicom blagoslivlja, a u povišenoj ljevici drži knjigu otvorenu na stranicama na kojima je ispisan tekst PAX VOBIS. Na unutarnji dio lakta desnice naslonio je biskupski štap. Zdesna njegovih nogu stoji bijela guska. Iza njih se nazire pozadina od niza raznobojnih pravokutnih polja. Lučni dio vitraja »nosi« frontalni prikaz krilatoga anđela crne kose u zelenoj odjeći i sklopljenih ruku u znaku molitve. Iza anđela je nedefinirana pozadina od romboidnih polja. Obrub vitraja čini niz narančastih romboidnih polja između trokutastih polja. Natpis o slikaru i poduzeću koje je izradilo vitraj nalazi se na prvome narančastom romboidnom stakalcu u donjemu desnom kutu vitraja.

Za izradu vitraja Pavle Vojković je osmislio četiri skice. Iz 1982. godine potječe skica rađena crnom olovkom i crnim flomasterom na papiru (slika 7.). ${ }^{26}$ Spram izvedenom vitraju, podudara se prikaz sv. Martina biskupa u središnjem dijelu vitraja ali izvedeni lik nema aureolu. Zanimljivo je da je umjetnik predvidio da središnji dio željeznom armaturom bude podijeljen na četiri jednaka dijela, ali izvedeni vitraj ima središnji dio podijeljen na dva jednaka djela. Lučni dio i obrub odstupaju. Obrub čini niz trokutaskih polja s točkama, a lučni dio prikaz Krista Pantokratora. Iste je godine slikar osmislio skicu Za Župnu crkvu »Sv. Martina«Vžd. Toplice / Prijedlog vitraja 2. (slika 8.), ${ }^{27}$ te signiranu i datiranu Vitrail za Župnu crkvu $» S v$. Martina« $u$ Varaždin. Toplicama (slika 9.). ${ }^{28}$ Njihovi identično osmišljeni prikazi razlikuju se u dekoraciji obruba (križ na vrhu). Obje skice izvedene su flomasterom u boji što omogućuje znatno lakšu usporedbu idejnih rješenja s konačnim vitrajem: prvotni je lik sv. Martina biskupa trebao nositi crveno-narančastu mitru iza koje se nalazi aureola, koja je izostala u konačnoj izvedbi, a lik Krista Pantokratora identičan je i obje verzije. Ispod skiciranoga vitraja teče Vojkovićeva bilješka II ${ }^{o}$ PROZOR U

${ }_{25}$ Pavle Vojković, Sv. Martin biskup, vitraj, 110 x 270 cm, svetište Župne crkve sv. Martina biskupa, Varaždinske Toplice.

26 Pavle Vojković, Skica za vitraj s prikazom Sv. Martina biskupa za Župnu crkvu sv. Martina u Varaždinskim Toplicama, 1983., olovka i flomaster na papiru, 35,5 x 56,4 cm. Iz ostavštine u vlasništvu gđe. Dragice Škarice.

27 Pavle Vojković, Za Župnu crkvu »Sv. Martina«Vžd. Toplice / Prijedlog vitraja 2., 1982., olovka i flomaster na papiru, 16,5 x $29 \mathrm{~cm}$. Iz ostavštine u vlasništvu gđe. Dragice Škarice.

28 Pavle Vojković, Vitrail za Župnu crkvu »Sv. Martina«Varaždin. Toplicama, 1982., olovka, flomaster i akvarel na papiru, 35,2 x 59,2 cm, Gradski muzej Varaždin, inv. br. GMV 62231. 
SVETIŠTU LIJEVO, koja potvrđuje slikarevu namjeru da se vitraj namijeni za otvor koji danas resi vitraj Sv. Martin i prosjak.

Četvrta i posljednja sačuvana skica za vitraj Sv. Martin biskup pokazuje najznačajniju promjenu u oblikovanju vitraja (slika 10.). ${ }^{29}$ Naspram prve skice, središnji dio nosi jednak ikonografski prizor sveca, a obrub vitraja drugačiju dekoraciju crvenkasta romboidna polja između žutih trokutastih polja. Najveća se promjena odnosi na prizor u lučnome djelu: Vojković je Krista Pantokratora zamijenio frontalnim prikazom mladolikoga krilatog anđela duge crne kose u zelenoj halji, ruku skupljenih u znaku molitve. S obzirom na navedeno, zaključuje se da je postojeći vitraj kombinacija dviju skica: prve iz 1982. godine s koje je preuzet lik biskupa i četvrte iz 1983. godine prema kojoj su oblikovani lučni dio s anđelom i obrub. Zanimljivo je da je Vojković na ovoj skici zamislio da bi romboidno stakalce $u$ donjemu desnom kutu vitraja »nosilo« natpis s podacima o autoru izvedbe i izrađivačima vitraja. Naposljetku, sačuvana je jedna skica - idejno rješenje za oblikovanje obruba svih triju vitraja, koje je Vojković osmislio između 1981. i 1982. godine (slika 12.). ${ }^{30} \mathrm{Na}$ papiru je nacrtao isječak obruba i ispod svakog kratko zapisao na koji se odnosi - BISKUP - KONJANIK - EVANĐEL. Dekoracija obruba za prizor Sv. Martin biskup odgovara obrubu postojećega vitraja. Dekoracija obruba za ostale prizore obojano romboidno između trokutastih stakalca - odstupa od konačne izvedbe.

29 Pavle Vojković, Skica za vitraj s prikazom Sv. Martina biskupa za Župnu crkou sv. Martina u Varaždinskim Toplicama, 1983., olovka i flomaster na papiru, 20,8 x 29,5 cm. Iz ostavštine u vlasništvu gđe. Dragice Škarice.

30 Pavle Vojković, Skica za dekoracije vitraja za Župnu crkvu sv. Martina biskupa u Varaždinskim Toplicama, između 1981. i 1983., flomaster na papiru, 29,5 x 20,8 cm. Iz ostavštine u vlasništvu gđe. Dragice Škarice. 


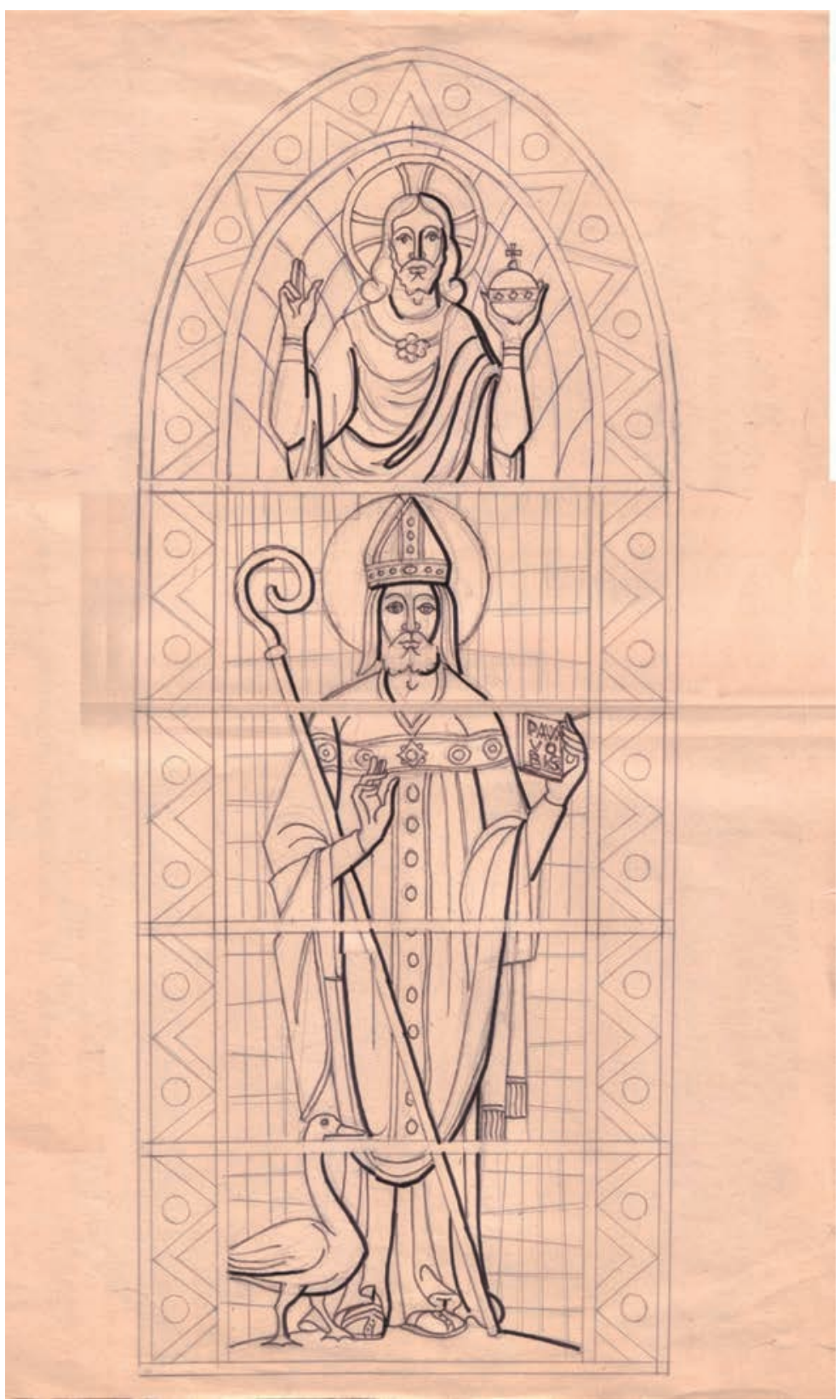

Slika 7. Pavle Vojković, Skica za vitraj s prikazom Sv. Martina biskupa za Župnu crkvu sv. Martina u Varaždinskim Toplicama, 1983., olovka i flomaster na papiru, 35,5 x 56,4cm. Iz slikareve ostavštine u vlasništvu gđe. Dragice Škarice. 


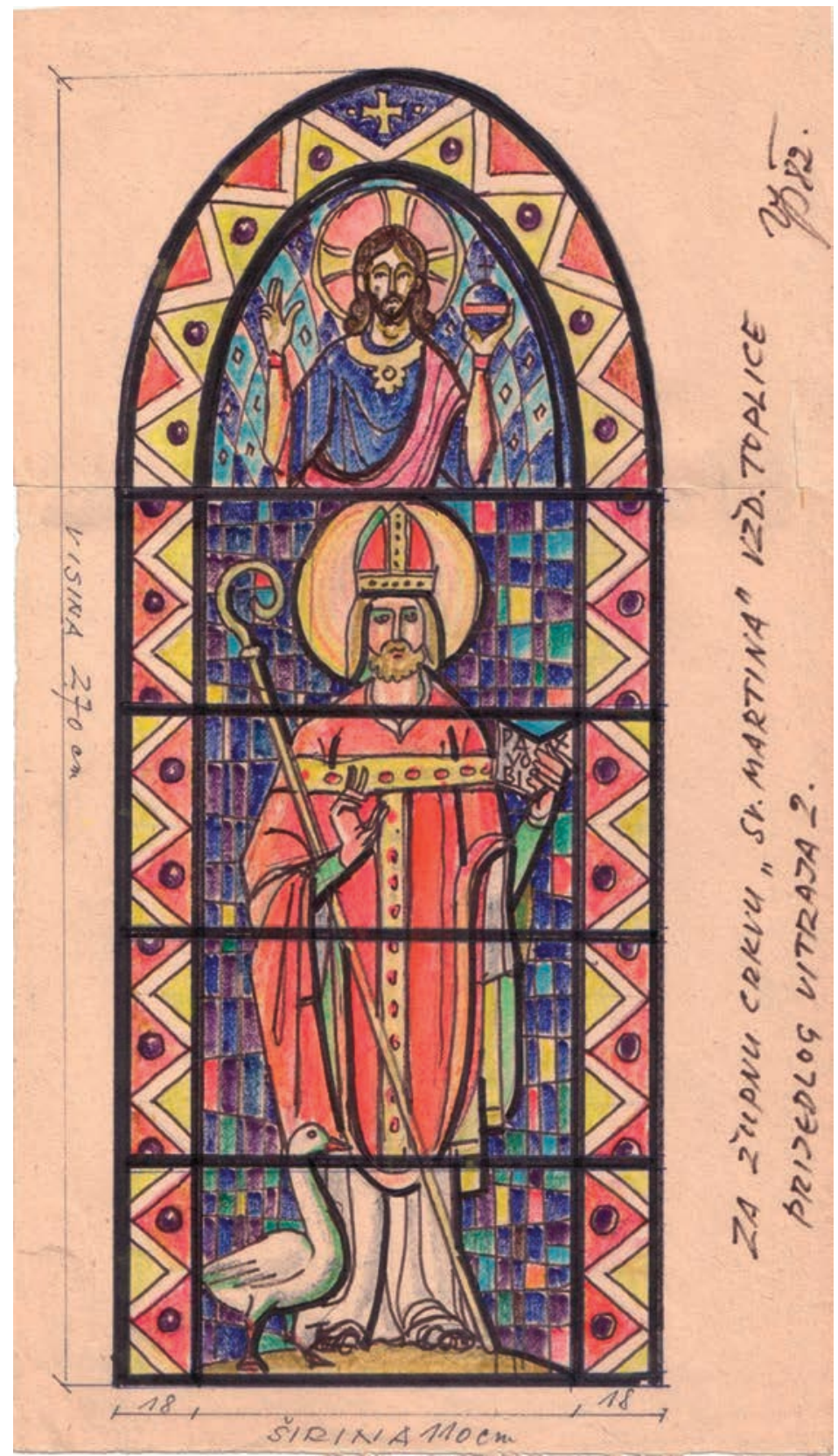

Slika 8. Pavle Vojković, Za Župnu crkvu »Sv. Martina« Vžd. Toplice / Prijedlog vitraja 2., 1982., olovka i flomaster na papiru, 16,5 × 29 cm. Iz slikareve ostavštine u vlasništvu gđe. Dragice Škarice. 


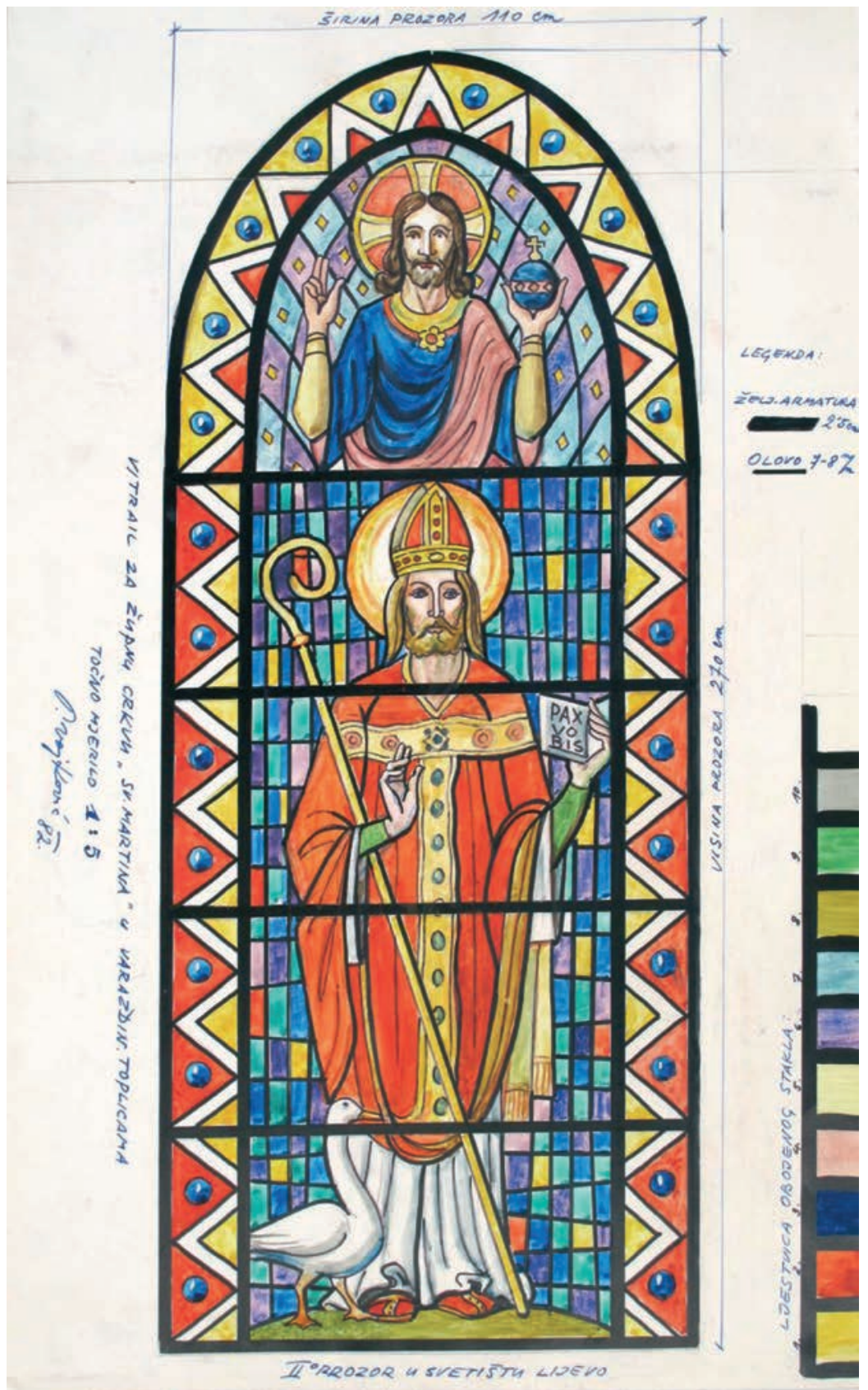

Slika 9. Pavle Vojković, Vitrail za Župnu crkvu "Sv. Martina« Varaždin. Toplicama, 1982., olovka, flomaster i akvarel na papiru, 35,2 x 59,2 cm, Gradski muzej Varaždin. 


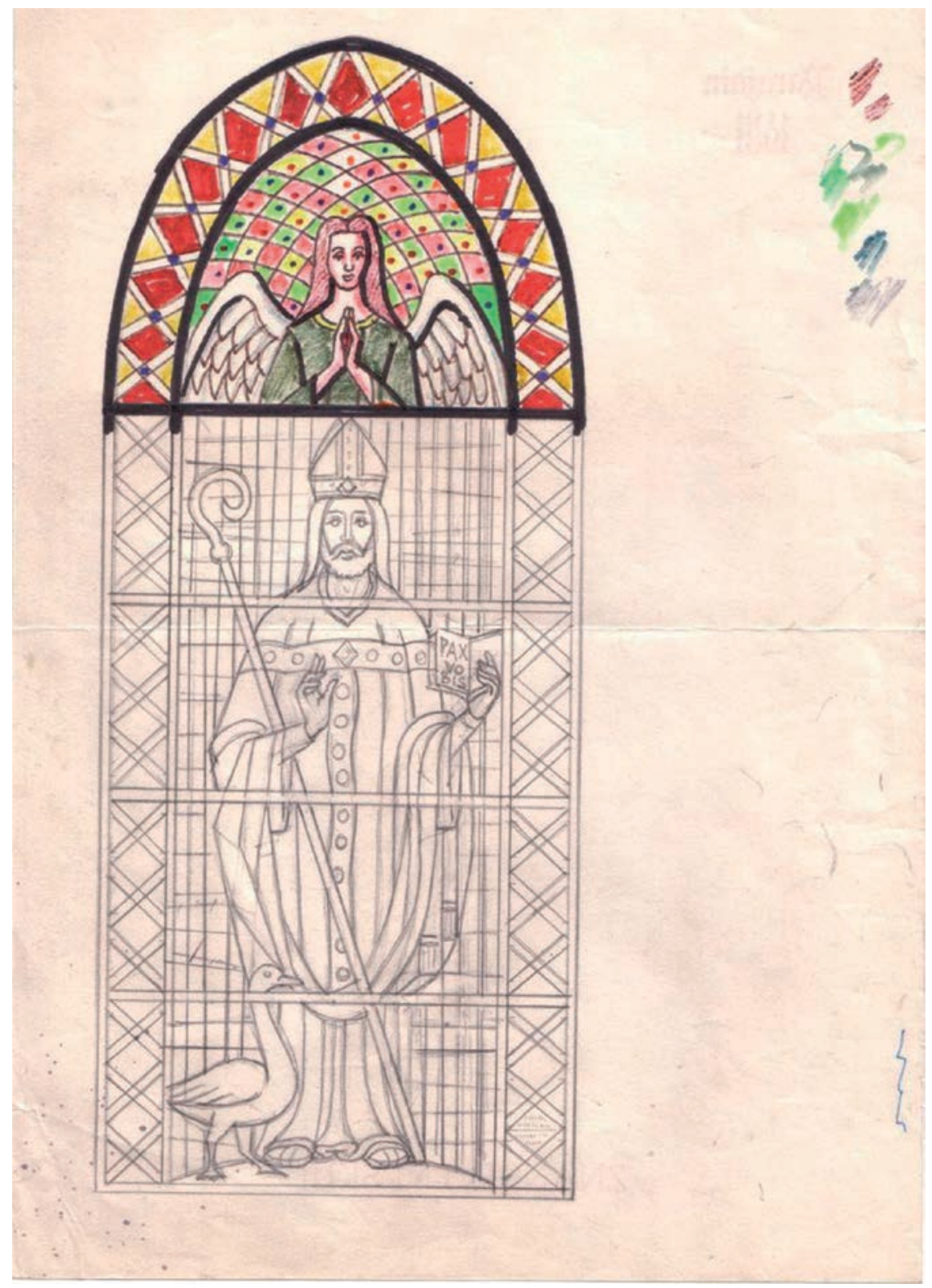

Slika 10. Pavle Vojković, Skica za vitrajs s prikazom Sv. Martina biskupa za Župnu crkvu sv. Martina u Varaždinskim Toplicama, 1983., olovka i flomaster na papiru, 20,8 x 29,5 cm. Iz slikareve ostavštine u vlasništvu gđe. Dragice Škarice. 


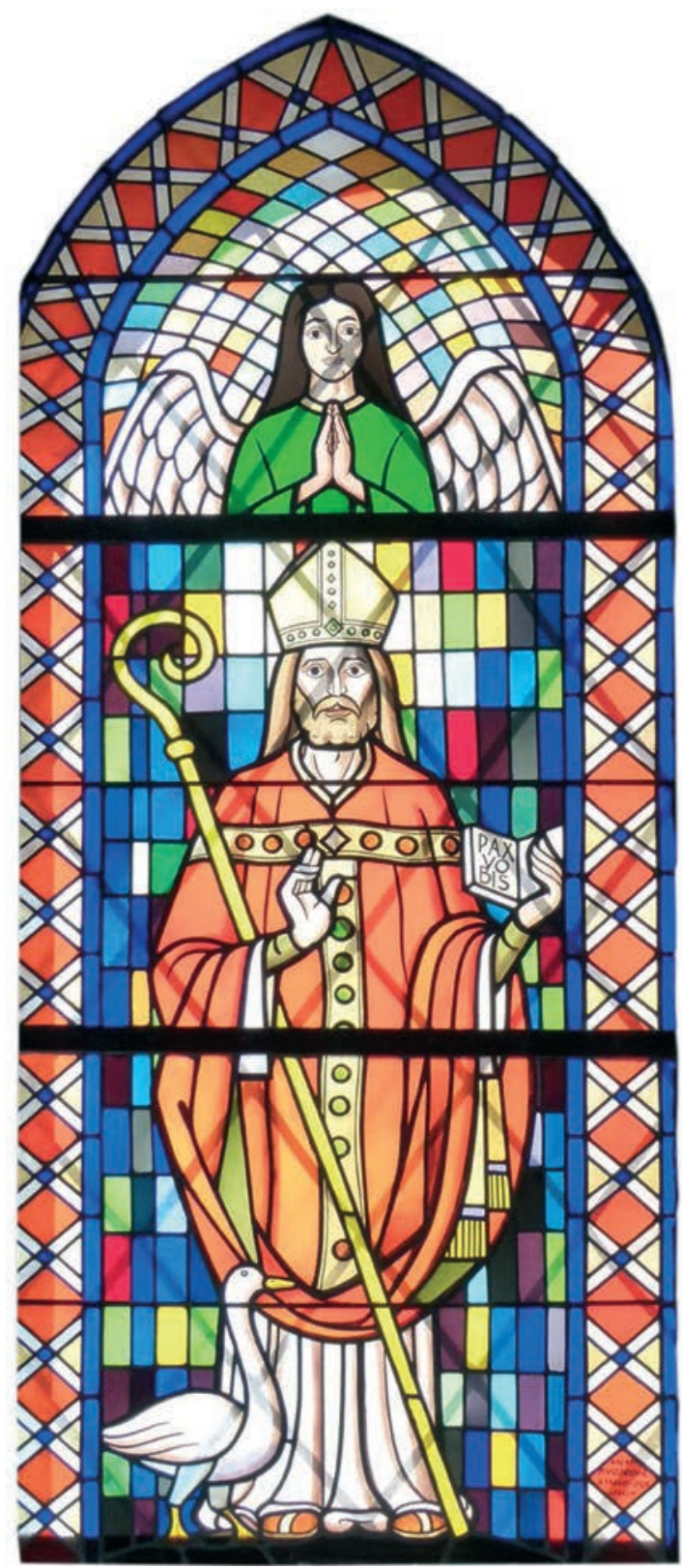

Slika 11. Pavle Vojković, Sv. Martin biskup, vitraj, 110 × 270 cm, svetište Župne crkve sv. Martina biskupa, Varaždinske Toplice. (Fotografiju obradio Ivan Kreč) 


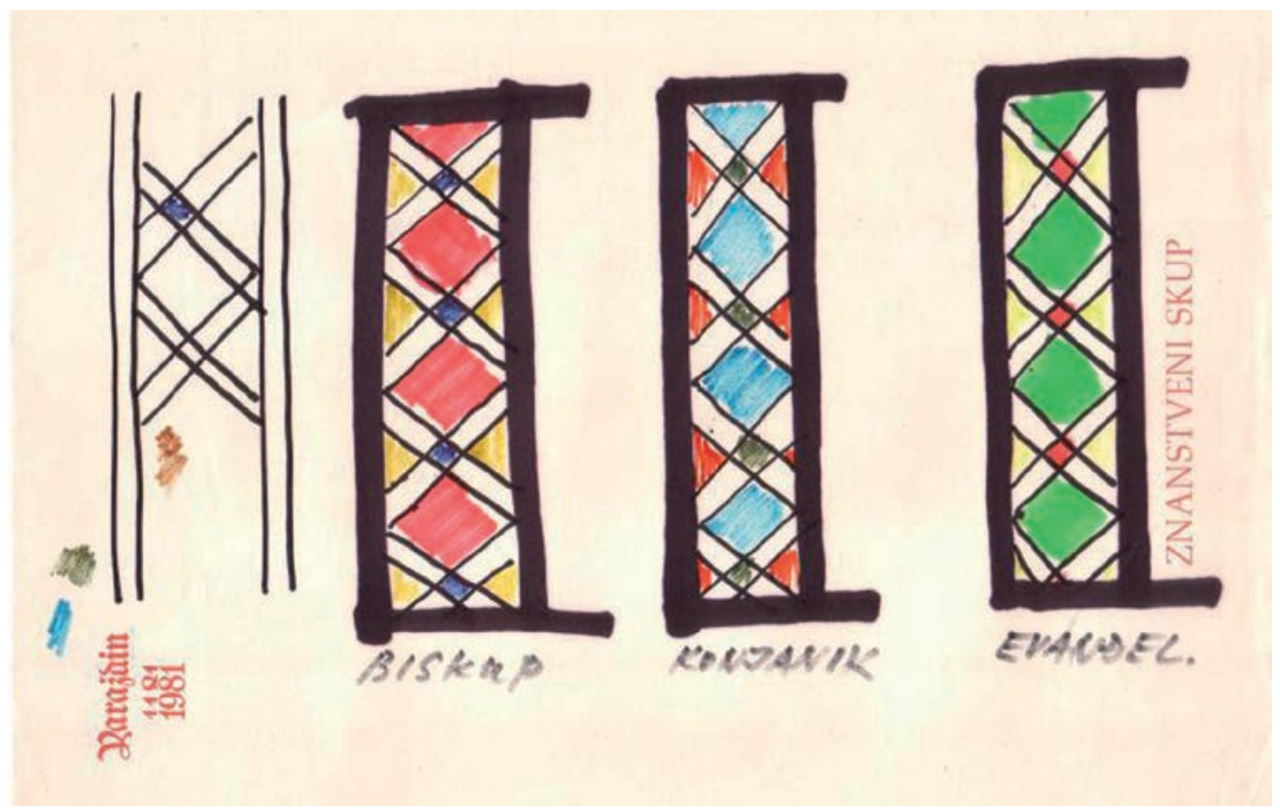

Slika 12. Pavle Vojković, Skica za dekoracije vitraja za Župnu crkvu sv. Martina biskupa u Varaždinskim Toplicama, između 1981.-1983., flomaster na papiru, 29,5 x 20,8 cm. Iz slikareve ostavštine u vlasništvu gđe. Dragice Škarice.

\section{O NARUČITELJU I IZRAĐIVAČU VITRAJA}

Zabilješka u župnoj spomenici ne navodi naručitelja izrade vitraja. Može se pretpostaviti da je riječ, najvjerojatnije, o župniku ili članovima topličke župe. Ne navodi se jesu li slikaru za izradu vitraja unaprijed bili zadani ikonografski prizori iz svečeva života ili ih je umjetnik samostalno odabrao s obzirom na titulara župne crkve. Ne može se ustvrditi ni točan razlog promjene ikonografskih prizora, niti promjene predviđenih smještaja za pojedine vitraje. Sačuvane skice otvaraju mnoga pitanja. Ukoliko je za prvi prozor na sjevernoj strani svetišta bio predviđen vitraj Sv. Martin i prosjak, a do njega Sv. Martin biskup, gdje je onda trebao biti smješten vitraj tetramorfa? Je li taj vitraj uopće i bio predviđen za smještaj na zid svetišta? Ne može se točno objasniti odabir ikonografskoga prizora tetramorfa. Može se objasniti prvotna odluka o smještaju vitraja sa svečevim likom za otvore na sjevernome zidu kako bi, jedan kraj drugoga, omogućili narativnost prizora: lijevi prizor se odnosi na događaj iz svečeva vojničkoga života, nakon čega se priča nastavlja događajem koji se zbio tik pred njegovim životom kao biskupa. Narativnost se zadržala pri konačnom smještaju vitraja na sjeverni i južni zid, tako što su oni ostaklili otvore koji se nalaze jedan nasuprot drugome. U oba slučaja 
narativnost prizora, odnosno, kronološki slijed zgoda iz života sv. Martina zadržan je »čitanjem « prizora u nizu, jedan za drugim, to jest, s lijeva na desnu stranu istoga zida ili s lijevoga zida na suprotni, desni zid svetišta.

Prema podacima iz župne spomenice, tri vitraja izradilo je poduzeće »Staklo« iz Zagreba, ali prema natpisu na vitraju Sv. Martin biskup Staklo-ZGB. S obzirom na njegov različito zabilježen naziv, je li riječ o istom izrađivaču vitraja? Prema dosadašnjim saznanjima, na hrvatskom tržištu trenutno ne djeluje poslovni subjekt Staklo-ZGB ili Staklo iz Zagreba. Međutim, potraga za izrađivačem vitraja autoricu ovog rada dovela je do pronalaska obrta Svijet staklo, djelatnom na hrvatskom tržištu od 1999. godine. Sudeći prema podacima na mrežnoj stranici Registra hrvatskih poslovnih internet stranica, poduzeće je nastalo »[...] poslije raspada poduzeća 'Staklo - Zagreb' područna jedinica Zadar [...]«, poduzeća iz koje je proizašao navedeni obrt. ${ }^{31}$ Je li moguće da je zadarska područna jedinica imala istoimeno matično poduzeće u Zagrebu? Autorica ovog rada e-mailom je stupila u kontakt s obrtom Svijet stakla koje je odgovorilo da je Staklo Zagreb imalo poslovnicu u Zagrebu i podružnicu u Zadru, te da je prestankom rada zagrebačke poslovnice njezin voditelj osnovao obrt u Zadru, Svijet stakla. ${ }^{32}$ Je li zagrebačka poslovnica poduzeće Staklo-ZGB koje je izradilo vitraje? Moguće je, iako se ne može točno ustvrditi.

\section{VITRAJI U KONTEKSTU IKONOGRAFIJE SVETIŠTA}

Početkom 1980-ih godina ikonografski prizori vitraja birani su najvjerojatnije u skladu s tadašnjom ikonografijom u župnoj crkvi, posebice svetišta dvotravejnoga pravokutnoga oblika s trostranim zaključkom. Četiri svodna polja u travejima svetišta »nose « prikaze četiriju evanđelista, tj. odraslih i starijih muškaraca u sjedećim položajima koji u rukama drže svoja evanđelja i kontemplativnim pogledom unatrag promatraju svoje simbolične prikaze. Prvo lijevo svodno polje bliže slavoluku crkve »nosi « prikaz sv. Mateja s krilatim čovjekom, a drugo lijevo polje sv. Marka s krilatim lavom. Prvo desno svodno polje bliže slavoluku »nosi« prikaz sv. Ivana s krilatim orlom, a bočno polje sv. Luke s krilatim volom. Ikonografija svodova objasnila bi odabir ikonografije vitraja s prikazom tetramorfa. Fotografije unutrašnjosti župne crkve sv. Martina biskupa u Varaždinskim Toplicama snimljene tijekom XX. stoljeća govore o tome da je se u crkvi nalazio, vjerojatno, jedini prikaz titulara

\footnotetext{
31 Poslovni forum, [»Registar hrvatskih poslovnih internet stranica«] »Poslovni Web Katalog «, Poslovni forum?, s.a. http://www.poslovniforum.hr/web-najtrazenije/links-najtrazenije.asp?cat=146 (pristupljeno 21. studenog 2016.). Usp. s podacima: Svijet stakla, »O nama«, Svijet stakla, 2016. http://www.svijetstakla.hr/o-nama (pristupljeno 21. studenog 2016.).

32 Iz korespodencije između autorice ovoga rada i zadarskoga obrta Svijet stakla, 23. studenog 2016. godine.
} 
župne crkve - uljana slika Sv. Martin biskup na glavnome oltaru za koji nije bila izvorno namijenjena. Fotografije su snimili Viktor Hoffiler 1919. godine, ${ }^{33}$ a nakon njega trideset godina poslije Artur Schneider. ${ }^{34}$ Obojica su zatekli identično stanje u svetištu. Dokumentirali su da su zidovi imali jednostavan dekorativan oslik: bočni zidovi zaključka tada su imali oslik zastora od kojih je onaj na južnom zidu u svom podnožju imao natpis $S v$. Metod, upućujući na to da vjerojatno skriva raniji oslik. Obojica su u župnoj crkvi zatekli barokne oltare sv. Katarine i sv. Barbare koje je barokni kipar Francesco Robba izradio za zagrebačku katedralu. Nakon potresa 1880. godine oltari su prema traženju Hermana Bolléa uklonjeni iz prvostolnice i četiri godine poslije postavljeni u topličku crkvu. ${ }^{35}$ Navedeni su ih istraživači zatekli u izmijenjenom obliku i međusobno razmiještenih skulptura. Uz sjeverni zid lađe nalazi se oltar sv. Barbare sa središnjim reljefom s prikazom svetičine muke između skulptura sv. Filipa Nerija i Stjepana prvomučenika. U svetištu su zatekli drugi oltar - i to promijenjena titulara. Na mjestu reljefa s prikazom svetičine muke nalazila se uljana slika Sv. Martin biskup između skulptura sv. Matije i Bartolomea, na izmijenjenoj atici neka skulptura Bogorodice. Uklonjeni reljef bio je zazidan u sjeverni zid lađe, iza propovjedaonice ${ }^{36}$. U novije doba glavnome je oltaru vraćen natrag izvorni reljef; uljana slika Sv. Martin biskup bila je premještena na atiku i uklonjena kako bi

33 Viktor HOFFILLER, »Radnje ljubljanskoga kipara Franje Robbe u Zagrebu«, Arheološki muzej u Zagrebu, Vjesnik Arheološkog muzeja u Zagrebu, sv. 14, Zagreb, br. 14, 1919., 220-226., vidi sl. 119-128.

34 Vidi fotografiju: Glavni oltar u svetištu župne crkve sv. Martina u Varaždinskim Toplicama, c/b fotografija, snimio Artur Schneider, 1940. godine. Strossmayerova galerija u Zagrebu. Izvješće obilaska: Artur SCHNEIDER, »Popisivanje i fotografijsko snimanje umjetničkih spomenika godine 1940.«, Jugoslavenska akademija znanosti i umjetnosti i Narodna tiskara, Ljetopis Jugoslavenske akademije znanosti i umjetnosti za god. 1939./1940.: Svezak 53, Zagreb, 1941., 183.

35 Napisnik znamenitijih dogadjajah i proimenah u župi Topličkoj-izvodjen počam od 1. studenoga 1863 godine po Eduardu Peroku upravitelju župe Topličke, za godinu 1884., bez paginacije.

36 Fotografiju reljefa uzidanog u zid lađe vidi u: Vlasta ZAJEC, »Izvještaji Artura Schneidera i fotografijski arhiv kao izvori za proučavanje nekadašnjih oltara zagrebačke katedrale«, Zbornik radova sa znanstveno-stručnog skupa Hrvatski povjesničari umjetnosti: Artur Schneider 1879.-1946., Društvo povjesničara umjetnosti Hrvatske, Zagreb, ur. Ljerka Dulibić, 2016., 210. U ovom radu autorica obraća pažnju na to da se u literaturi različito navode godine postavljanja oltara u zagrebačku prvostolnicu. Vidi str. 213: »U literaturi se različito navodi i vrijeme podizanja oltara koji su, prema ugovoru sklopljenom između Robbe i Patola 1727. godine, trebali biti dovršeni 1279., no njihova se realizacija, kako se može zaključiti iz sadržaja više tužbi podignutih protiv kipara, znatno otegnula. Schneider se nastanak oltara sv. Barbare smješta u 1733., a oltara posvećena sv. Katarini 1731. Nije poznato na osnovi čega se odlučio za upravo takvo datiranje koje se razlikuje kako od Tkalčićeva, koji navodi da je oltar sv. Katarine dovršen 1732., a oltar sv. Barbare postavljen oko 1722., tako i od Jiroušekova, koje će istaći da su oltari dovršeni znatno kasnije nakon sklapanja ugovora - oltar sv. Barbare po svojoj prilici nakon 1746. U nedostatku čvršćih uporišta za dataciju, u novije će vrijeme Matej Klemenčić za oba oltara oprezno navesti da nastaju u vremenu od 1728. nadalje«. U posljednjem komentaru autorica se osvrće na rad: Matej KLEMENČIČ, Francesco Robba (1698-1757): beneški kipar in arhitekt v baročni Ljubljani, Umetniski kabinet Primoz Premzl, Maribor, 2013., 271-272. 
napravila mjesta skulpturi koja moguće prikazuje sv. Martina biskupa. ${ }^{37}$ Tijekom nedavnih konzervatorskih i restauratorskih radova u 2013. godini, na unutarnjim zidovima svetišta uklonjen je oslik s prikazom zastora koji je sakrivao raniji oslik s prizorom stojećih figura sv. Ćirila i sv. Metoda, nepoznatoga autora za koje se misli da su nastale »i prije oslikavanja crkve 1885. godine. Robbini oltari iz zagrebačke katedrale postavljeni su 1884. godine pa je za pretpostaviti da su sv. Ćiril i Metod tada uklonjeni kako bi oltari došli do izražaja «. ${ }^{38}$ Međutim, uljana slika Sv. Martin biskup uklonjena je u župni dvor i izlaže se na blagdan titulara crkve, na 11. studenoga. Tijekom radova na obnovi oltara Francesca Robbe 2016. godine sagrađena je provizorna skela za obnovu oltara koja je omotana tkaninom, na skelu ispred glavnoga oltara ovješena je spomenuta uljena slika. Zaključuje se da je u XX. stoljeću do postava vitraja jedini ikonografski prikaz titulara u crkvi predstavljala slika $S v$. Martin biskup na glavnom oltaru koja za taj oltar nije bila ni predviđena, a postavljenja je na njega iz potrebe da se glavni oltar postavi djelo s prikazom lika titulara. Time se i objašnjava zamjena lika svetice na atici novijom skulpturom titulara. Očekivani smještaj umjetničkoga djela koje nosi lik titulara sakralne građevine obično je glavni oltar, često njegov središnji dio. Postaje razumljiv odabir njihovih ikonografskih prizora čime se u svetištu naglasio titular topličke crkve i u tome se nalazi i njihov značaj - oni jedini nose ikonografske prizore titulara crkve, ne u samom svetištu, nego i u cijeloj crkvi.

\section{VITRAJI U KONTEKSTU SLIKAREVA OPUSA}

Vitraji Sv. Martin i prosjak i Sv. Martin biskup stilski su srodniji, nego svaki od njih naspram vitraja tetramorfa. U stilskoj analizi triju vitraja Pavla Vojkovića uzima se u obzir i sama tehnika za koju su rađeni - vitraja, koju označavaju određene tehničke / izvedbene mogućnosti, što se često puta ogleda u ograničenom načinu prikazivanja mnoštva detalja, dubine ili suptilne tonske gradacije. U skiciranju tih vitraja Pavle Vojković se izražavao jednostavnim crtežom i kolorističkom ljestvicom od desetak različitih boja, i to najviše dva tona jedne boje. Tako je za izradu vitraja Sv. Martin

\footnotetext{
Slika Sv. Martin biskup restaurirana je 2013. godine u Restauratorskom centru Ludbreg Hrvatskoga restauratorskoga zavoda u Zagrebu. Na podacima o slici i promjenama na glavnom oltaru autorica ovoga rada srdačno zahvaljuje gđi. Veniji Bobnjarić-Vučković, konzervatorici savjetnici i voditeljici ludbreškoga centra. Fotografiju stanja svetišta župne crkve 2013. godine vidi: Ana KANIŠKI, "Schneiderov fotografijski arhiv umjetničke baštine Hrvatskog zagorja i utjecaj Gjure Szabe«, Zbornik radova sa znanstveno-stručnog skupa Hrvatski povjesničari umjetnosti: Artur Schneider 1879.-1946., Društvo povjesničara umjetnosti Hrvatske, Zagreb, ur. Ljerka Dulibić, 2016., 256. (sl. 6).

38 Radove na unutarnjim zidovima svetišta radio je Slikarsko-restauratorski obrt »Genc« iz Bednje. Na podacima o radovima i e-mail korespodenciji zahvaljujem župniku Stjepanu Mostečaku.
} 

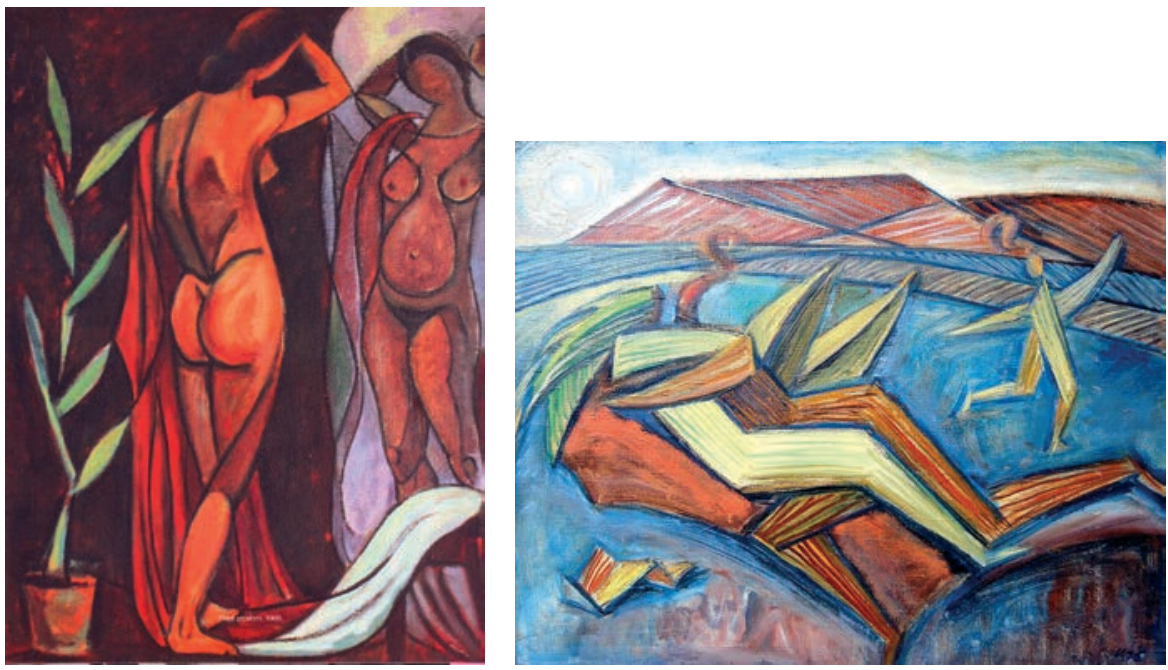

LIJEVO: Slika 13. Pavle Vojković, Pred zrcalom, 1968. ulje na platnu, $99 \times 72 \mathrm{~cm}$, sign. d.d.k. V, privatno vlasništvo, Varaždin. Preuzeto iz: Pavle Vojković, 2012., 46 i 72.

DESNO: Slika 14. Pavle Vojković, Igra jesenjeg vjetra, 1976., ulje na platnu, 50 x 61,5 cm, sign. d.d.k. V. 76., Gradski muzej Varaždin.
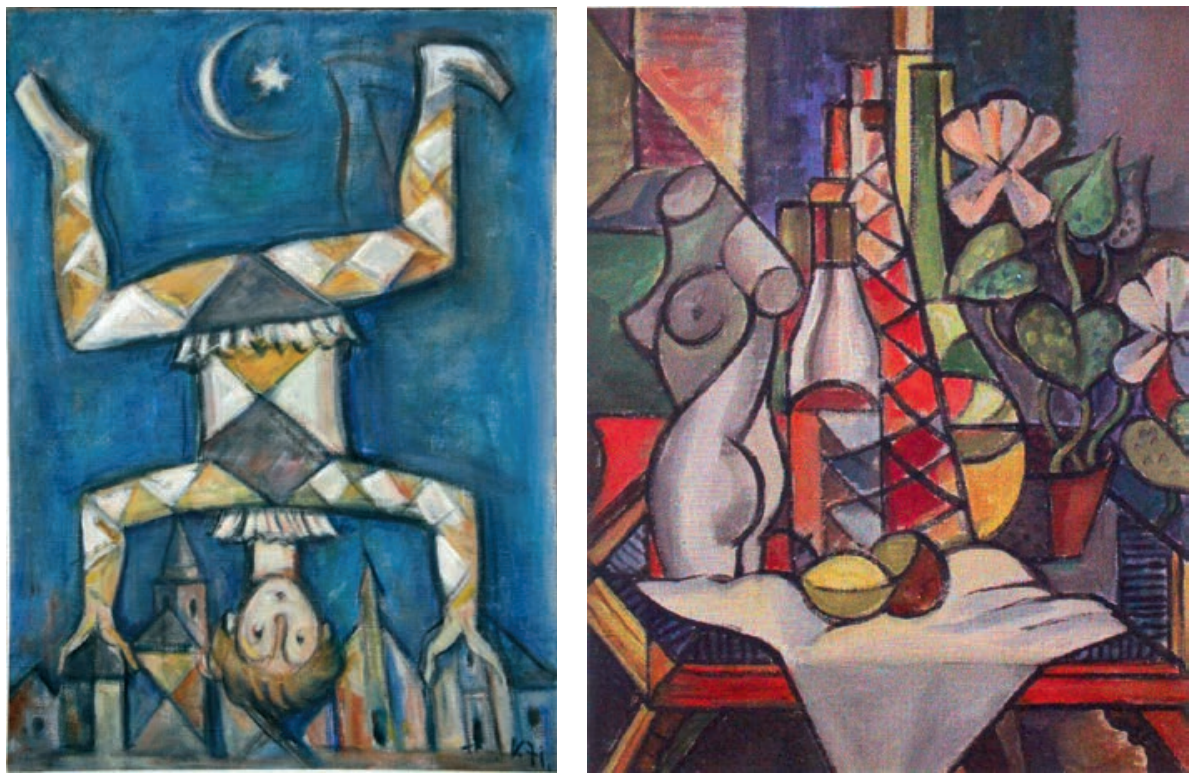

LIJEVO: Slika 15. Pavle Vojković, Sizif u Varaždinu, 1971., ulje na platnu, 100 x 73 cm, sign. d.d.k. V. $71 .$, Gradski muzej Varaždin.

DESNO: Slika 16. Pavle Vojković, Mrtva priroda sa skulpturom, 1982., ulje na platnu, 55 x 45,5 cm, sign. d.d.k. V. 82., vl. obitelji Hršak Bonjeković, Varaždin. Preuzeto iz Pavle Vojković, 2012., 66 i 73. 
biskup predvidio jedanaest različito obojenih stakalca (dva tona - svjetla i tamnija žuta, crvena, plava, zelena, te jedan ton smeđe i ljubičaste). Vitraji su građeni poljima / komadima obojenih stakalca, a međusobno razdijeljenima jednostavnim ravnim i valovitim linijama, kojima oblikuje prizor i pojedine detalje. Ritmičkim iscrtavanjem valovitih linija oblikovao je grivu konja bijelca i stvorio dubinu gustih nabora vojnikova plašta, rasterom ritmiziranih horizontalnih i okomitih linija pozadinu iza figura biskupa, Krista Pantokratora i anđela. Dojam gustih nabora plašta i grube teksture prosjakovih prnja stvorio je korištenjem emajla na obojenom staklu, kojim je naznačio i detalje lica figurama i konju (oči, nos, usta, prsti ruku i stopala, tamnija griva bijelca, sjenčanje nadlaktica vojnika, sjenčanje duge prosjakove kose kako bi se istaknulo svjetlije tjeme dajući dojam izvora svjetlosti koje mu osvjetljuje kosu). Međutim, na trima vitrajima dominira kolorit. Uz liniju, Pavle Vojković je kompoziciju gradio nizom polja / komada stakalca različitih boja, nerijetko suprotstavljajući nekoliko različitih boja, što je najjasnije vidljivo u oblikovanju nedefiniranih pozadina iza figura biskupa, Krista Pantokratora, anđela i čovjekolikoga sunca, te i u prikazu krajolika iza figure viteza koji čine plavkasta brda i žućkasto, narančasto i ljubičasto nebo. Jednako izražavanje koloritom značajno je za vitraj tetramorf. Pavle Vojković ga je skicirao strogim crtežom i nizom jednostavnih linija kojima je oblikovao reducirane figure lišene svih detalja približivši se pritom apstrakciji.

Osim u kontekstu tehnike izrade, sačuvane skice i vitraje moguće je promatrati u kontekstu slikareva cjelokupnoga slikarskog opusa, koji prema zaključku Mirjane Dučakijević, prati nekoliko razvojnih faza. ${ }^{39} \mathrm{U}$ svrhu analize vitraja, potrebno se osvrnuti na slikareve tri sukcesivne faze: fazu apstrakcije 1960-ih i 1970-ih godina, fazu linearizma i statičnosti 1980-ih godina i fazu strukture krajem 1980-ih godina. U razdoblju (semi)apstrakcije Pavle Vojković se izražavao jednostavnim strogim crtežom i kolorističkom redukcijom. Na slici Pred zrcalom (1968.) jednostavnim crnim linijama izgradio je stojeću figuru vitke nage žene koja promatra svoj odraz u zrcalu (slika 13). ${ }^{40}$ Debelim crnim linijama obrubio je plošno oblikovano žensko tijelo, te je gipko ritmizirao nabore plašta koji pada duž lijeve strane tijela. Tamniji tonovi crvene i rubinske boje pri kraju plašta iznenadno su pretvoreni u svjetlo plave. U odnosu na ovu sliku, svega petnaestak godina poslije slikar je sličnim ritmiziranjem linija predstavio i plašt vojnika Martina i koloristički ga suprotstavio plavetnilu njegove odore.

39 Pišući o cjelovitom opusu Pavla Vojkovića, autorica izložbe Mirjana Dučakijević razlučila je nekoliko razvojnih faza: akademija i raniji radovi (1936.-1942.), faza kubističkih rješenja (1940.-1942.), urbanistička i pejzažna tematika (1940.-ih), povratak intimizmu (1954.-1960.), apstrakcija (1960.-1970.), statika i linearizam (1980-ih) i struktura (1988.). Vidi: Pavle Vojković, 2012., 5-8.

40 Pavle Vojković, Pred zrcalom, 1968. ulje na platnu, 99 × $72 \mathrm{~cm}$, sign. d.d.k. V, privatno vlasništvo, Varaždin. Vidi u: Ibidem, 46 i 72. 
Sliku Igra jesenjeg vjetra (1976.) čini niz geometrijskih polja koja su odijeljena debelom tamnom linijom $\mathrm{i}$ »obojana « ritmičkim iscrtavanjem linija tamnije i svjetlije boje, tako dajući dojam nebrojenih tonskih polja koloristički suprotstavljenih (slika 14). ${ }^{41}$ Ista se ideja može vidjeti u načinu kojim je slikar koloristički osmislio pozadinu iza figura biskupa, Krista Pantokratora i anđela - nizom sitnih stakalca suprotstavljenoga kolorita što se najjasnije nazire i na vitraju tetramorf. Na slici Sizif u Varaždinu (1971.) grčki mitološki lik nosi šaljivi kostim sašiven od bijelih, žutih i ljubičastih komada tkanine (slika 15). ${ }^{42}$ Takvu dekorativnost i sučeljavanje raznoobojenih trokuta jedanaest godina poslije slikar je ponovio u oblikovanju dekorativnog obruba svih triju vitraja u župnoj crkvi. U fazi linearizma i statičnosti nastala je slika Mrtva priroda sa skulpturom (1982.) gdje je također tamnom linijom obrubio ženski torzo, boce i teglu cvijeća na stolu i razložio ih na koloristička i tonska polja (slika 16). ${ }^{43}$ Takvim slikarskim izrazom, kojim se koristio u godini nastanka prvih skica vitraja, označit će sliku Kain i Abel (1985.) gdje će pozadinu iza biblijskih likova činiti polja čiste boje. ${ }^{44}$ Može se zaključiti da se pojedini slikarski elementi kojima je Vojković oblikovao skice i posljedno time vitraje, javljaju još i petnaestak godina prije nastanka prvih skica. Odnosno, stilski gledano skice čine dio razvojnih faza njegova likovnoga opusa. Iako stilski ostaju u okvirima toga opusa, vitraji su značajni u kontekstu župne crkve jer predstavljaju pomak u smjeru suvremene likovne umjetnosti. ${ }^{45}$

${ }_{41}$ Pavle Vojković, Igra jesenjeg vjetra, 1976., ulje na platnu, 50 x 61,5 cm, sign. d.d.k. V. 76., Gradski muzej Varaždin, inv. br. GMV 55224. Vidi u: Ibidem, 43 i 73.

42 Pavle Vojković, Sizif u Varaždinu, 1971., ulje na platnu, $100 \times 73$ cm, sign. d.d.k. V. 71., Gradski muzej Varaždin, inv. br. GMV 56444. Vidi u: Ibidem, 72. i poleđina kataloga.

43 Pavle Vojković, Mrtva priroda sa skulpturom, 1982., ulje na platnu, 55 x 45,5 cm, sign. d.d.k. V. 82., vl. obitelji Hršak Bonjeković, Varaždin. Vidi u: Ibidem, 66 i 73.

44 Pavle Vojković, Kain i Abel, ulje na platnu, 55 x 45,5 cm, sign. d.d.k. P Vojković 85, Gradski muzej Varaždin, inv. br. GMV 55228. Vidi u: Ibidem, 73.

45 Za ostala slikarska i skulpturalna djela u župnoj crkvi vidi opis u: ĐURIĆ, 2009./2010., 13-15. 


\section{LITERATURA}

\section{Neobjavljena djela:}

1. Napisnik znamenitijih dogadjajah i proimenah u župi Topličkoj - izvodjen počam od 1. studenoga 1863 godine po Eduardu Peroku upravitelju župe Topličke, spomenica župe sv. Martina biskupa u Varaždinskim Toplicama.

\section{Skice Pavla Vojkovića:}

Skice Pavla Vojkovića iz Zbirke Pavle Vojkovića Gradskoga muzeja Varaždin:

1. Vitrail za župnu crkvu »Sv. Martin« u Varaždinskim Toplicama, 1982., olovka i flomaster na papiru, 35,3 x 59,3 cm, Gradski muzej Varaždin, inv. br. GMV 65100.

2. Skica za vitraj s prikazom Sv. Martina i prosjaka za Župnu crkvu sv. Martina u Varaždinskim Toplicama, 1983., olovka, flomaster i akavrel na papiru, 35,3 x 59,3 cm, Gradski muzej Varaždin, inv. br. GMV 65099.

3. Vitrail za Župnu crkvu »Sv. Martina«Varaždin. Toplicama, 1982., olovka, flomaster i akvarel na papiru, 35,2 x 59,2 cm, Gradski muzej Varaždin, inv. br. GMV 62231.

Skice Pavla Vojkovića iz slikareve ostavštine u vlasništvu gđe. Dragice Škarice:

1. Skica za vitraj s prikazom Sv. Martina i prosjaka za Župnu crkvu sv. Martina u Varaždinskim Toplicama, 1983., olovka i flomaster na papiru, 25,5 x 35,5 cm.

2. Za Žup. cr[kvu »Sv. Martina«] Vžd. Toplice, 1982. ili 1983., flomaster na papiru, $23,5 \times 29,5 \mathrm{~cm}$.

3. Skica za vitraj s prikazom Sv. Martina biskupa za Župnu crkvu sv. Martina u Varaždinskim Toplicama, 1983., olovka i flomaster na papiru, 35,5 x 56,4 cm.

4. Za Župnu crkvu »Sv. Martina«VŽd. Toplice / Prijedlog vitraja 2., 1982., olovka i flomaster na papiru, $16,5 \times 29 \mathrm{~cm}$.

5. Skica za vitrajs s prikazom Sv. Martina biskupa za Župnu crkvu sv. Martina u Varaždinskim Toplicama, 1983., olovka i flomaster na papiru, 20,8 x 29,5 cm.

6. Skica za dekoracije vitraja za Župnu crkvu sv. Martina biskupa u Varaždinskim Toplicama, između 1981.-1983., flomaster na papiru, 20,8 x 29,5 cm. 


\section{Objavljene monografije, radovi, knjige, enciklopedije i leksikoni:}

1. "stained glass«, The Oxford Dictionary of Art and Artists, Ian Chilvres, Oxford, 2009.

2. Tomislav ĐURIĆ, Crkvena baština varaždinsko-topličkog kraja: Posvečeno 70. godišnjici života Tomislava Đurića, Meridijani, Varaždinske Toplice - Samobor, 2009./2010.

3. vitrail«, Enciklopedija likovnih umjetnosti: Sv. 4: Portr- Ž, Dodatak, gl. red. Slavko Batušić, Andre Mohorovičić, Mirko Šeper, Zagreb, 1966.

4. »Martin of Tours«, The Oxford Dictionary of Saints, David Hugh Farmer, Oxford, [1978.] 2011.

5. Božena FILIPAN, »Barokna baština Varaždinskih Toplica s osvrtom na zaštitu i revitalizaciju «, Hrvatska akademija znanosti i umjetnosti, Radovi Zavoda za znanstveni rad Varaždin, Varaždin,, br. 8/9, 1996., 41-73.

6. Viktor HOFFILLER, »Radnje ljubljanskoga kipara Franje Robbe u Zagrebu«, Arheološki muzej u Zagrebu, Vjesnik Arheološkog muzeja u Zagrebu, sv. 14, Zagreb, br. 14, 1919., 205-235.

7. Ana KANIŠKI, »Schneiderov fotografijski arhiv umjetničke baštine Hrvatskog zagorja i utjecaj Gjure Szabe«, Zbornik radova sa znanstveno-stručnog skupa Hrvatski povjesničari umjetnosti: Artur Schneider 1879.-1946., Društvo povjesničara umjetnosti Hrvatske, Zagreb, ur. Ljerka Dulibić, 2016., 243.-259.

8. Matej KLEMENČIČ, Francesco Robba (1698-1757): beneški kipar in arhitekt v baročni Ljubljani, Umetniski kabinet Primoz Premzl, Maribor, 2013.

9. Martin biskup, sveti«, Leksikon ikonografije liturgike i simbolike zapadnog kršćanstva [IV. dopunjeno izdanje], ur. Anđelko Badurina, Zagreb, 2000.

10. »vitraj«, Likouni leksikon, gl. ur. Josip Bilić, Zagreb, 2014.

11. Pavle Vojković: retrospektiva: 1936.-1991.: Galerija slika Varždin, 3. 6. - 4. 8. 1991., Varaždin, Gradski muzej Varaždin, 1991

12. Pavle Vojković [Povodom stote obljetnice rođenja Pavla Vojkovića. Retrospektiona izložba 4. 12. 2012. - 3. 3. 2013.], Gradski muzej Varaždin, Varaždin, 2012.

13. Louis RÉAU, Iconographie de L'art Chrétien: Iconographie des Saints II: G-O, Presses Universitaires de France, Paris, 1958.

14. Artur SCHNEIDER, »Popisivanje i fotografijsko snimanje umjetničkih spomenika godine 1940.«, Jugoslavenska akademija znanosti i umjetnosti i Narodna tiskara, Ljetopis Jugoslavenske akademije znanosti i umjetnosti za god. 1939./1940.: Svezak 53, Zagreb, 1941., 176-184.

15. »stained glass «, The New Encyclopaedia Britannica. Micropaedia: ready reference. 11, Solovyov-Truck, 15th Edition, ur. Robert Gwinn, Chicago, 1995. 
16. »Stained glass«, The World Book Encyclopedia: Volume 18: So-Sz, Chicago, 1994.

17. Jacobus de VORAGINE, The Golden Legend or Lives of Sints as Englished by William Caxton: Vol. Six, ed. F. S. Ellis, J. M. Dent and Co. i Aladine House, London, 1900.

18. Vlasta ZAJEC, »Izvještaji Artura Schneidera i fotografijski arhiv kao izvori za proučavanje nekadašnjih oltara zagrebačke katedrale«, Zbornik radova sa znanstveno-stručnog skupa Hrvatski povjesničari umjetnosti: Artur Schneider 1879.-1946., Društvo povjesničara umjetnosti Hrvatske, Zagreb, ur. Ljerka Dulibić, 2016., 191-223.

\section{Mrežne stranice:}

1. Poslovni forum, [»Registar hrvatskih poslovnih internet stranica«] »Poslovni Web Katalog«, Poslovni forum?, s.a. http://www.poslovniforum.hr/web-najtrazenije/ links-najtrazenije.asp?cat=146 (pristupljeno 21. studenog 2016.)

2. Svijet stakla, »O nama«, Svijet stakla, 2016. http://www.svijetstakla.hr/o-nama (pristupljeno 21. studenog 2016.)

\section{SAŽETAK}

\section{VITRAJI PAVLA VOJKOVIĆA U ŽUPNOJ CRKVI SV. MARTINA BISKUPA U VARAŽDINSKIM TOPLICAMA}

Godine 1983. svetište župne crkve sv. Martina biskupa u Varaždinskim Toplicama dobiva tri vitraja koje je prema skicama akademskoga slikara, scenografa i kostimografa Pavla Vojkovića (Varaždin, 24. lipnja 1912. - 26. prosinca 2006.) izradilo poduzeće »Staklo« iz Zagreba. Njegovi su šiljato zaključeni pravokutni gotički otvori ostakljeni vitrajima s najznačajnijim ikonografskim prizorima iz života titulara topličke crkve. Na sjevernom zidu svetišta gotički otvor bliži slavoluku »nosi« vitraj s prikazom tetramorfa, simbola četiriju evanđelista. Njemu zdesna gotički otvor »nosi « vitraj Sv. Martin i prosjak, nasuprot njemu na južnome zidu svetišta postavljen je vitraj s prizorom Sv. Martin biskup. Podaci o trima vitrajima, osim njihova smještaja u svetištu, zabilježeni su u župnoj spomenici, na nepaginiranoj stranici ispod niza zapisa za 1983. godinu. Podatak da su izvedeni prema skicama varaždinskoga umjetnika potvrđuje i natpis NACRT / P. VOJKOVIĆ / STAKLO - ZGB / IZVELO, zapisan u donjemu desnom kutu vitraja Sv. Martin i biskup. Zabilješku u župnoj spomenici i natpis na vitraju potvrđuju devet sačuvanih skica koje je slikar izradio 1982. i 1983. godine. Dio su Zbirke Pavla Vojkovića Gradskog muzeja Varaždin i slikareve ostavštine u privatnom vlasništvu - daju uvid u raspone sakralnog opusa Pavla Vojkovića koji dosad nije bio obrađivan. Usporede li se skice s vitrajima, zaključuje se da je slikar u dvije godine promijenio ikonografska i kompozicijska rješenja prizora triju vitraja. Ikonografski prizori birani su najvjerojatnije u skladu s ikonografijom u župnoj crkvi: do vitraja koji su postavljeni 1983. godine, jedini prikaz titulara crkve 
bila je uljana slika Sv. Martin biskup na glavnom oltaru za koji izvorno nije ni namijenjena. Preseljenjem te slike u župni dvor, vitraji su postali jedini nosioci ikonografije titulara u crkvi. Slikarski elementi kojima je Pavle Vojković oblikovao skice i vitraje pojavljuju se još i petnaestak godina prije nastanka prvih skica. Odnosno, stilski gledano skice, time i vitraji, čine dio razvojnih faza njegova opusa: fazu apstrakcije 1960-ih i 1970-ih godina, fazu linearizma i statičnosti 1980-ih godina i fazu strukture krajem 1980-ih godina. Iako se stilski ne izdvajaju iz njegovoga opusa, vitraji postaju značajni u kontekstu župne crkve jer su među prvima djelima suvremene likovne umjetnosti u župnoj crkvi.

Ključne riječi: vitraj; ikonografija; sv. Martin i prosjak; sv. Martin biskup; tetramorf; Pavao Vojković; župna crkva; Varaždinske Toplice; suvremena sakralna umjetnost.

\section{SUMMARY}

\section{PAVAO VOJKOVIĆ'S STAINED GLASS WINDOWS IN THE CHURCH OF ST. MARTIN THE BISHOP IN VARAŽDINSKE TOPLICE}

In 1983, three stained-glass windows designed by the painter, costume and set designer Pavao Vojković (b. June 24, 1912 - d. December 26, 2006 in Varaždin), and manufactured by the Zagreb glassmaking company Staklo, were installed in the Church of St. Martin the Bishop in Varaždinske Toplice. The rectangular Gothic windows topped with lancet arches are adorned with stained-glass images showing key episodes of the saint's life. On the northern wall of the church, in the Gothic opening that stands closer to the arch, there is a stained-glass window with a tetramorph, the symbol of the Four Evangelists. The window on its right shows St Martin and the Beggar, while on the opposite, southern wall, there is an image of St Martin the Bishop. The information concerning the three stained-glass windows, apart from their locations, is listed on an unnumbered page of the parish chronicle, under a series of notes from 1983. That the windows were made after the artist's designs corroborates the inscription NACRT / P. VOJKOVIĆ / STAKLO - ZGB / IZVELO, (DESIGN / P. VOJKOVIĆ / STAKLO-ZGB / MANUFACTURER) found in the lower left corner of the stained-glass window depicting St. Martin the bishop. The inscription and the note in the parish chronicle tie in with nine surviving sketches made by the artist in 1982 and 1983. These are kept in the Pavao Vojković Collection of the Varaždin City Museum, and a private collection of the artist's work, forming a significant part of his religious oeuvre. Comparing the sketches with the windows highlights the changes in the iconography and composition of the scenes on the three windows. These were most probably selected to match the existing iconography: until the windows were installed in 1983, an oil painting of St. Martin on the main altar, not originally intended for it, was the only image of the saint Martin of Tours inside the church. Following the relocation of the painting to the parish house, the windows remain the only examples of the saint's iconography in the church. The elements that Vojković used in the sketches and windows predate them by as much as fifteen years. Therefore, in terms of style, the sketches and the windows fit into the developmental phases of his work: the abstract phase (1960s-1970s), the linearist and static phase (in the 1980s) and the structure phase from the late 1980s. Although 
the stained glass windows do not stand out from the rest of his work in this sense, they are significant for the church itself, as one of the first contemporary works of art in the parish church.

Key Words: stained glass; iconography; St. Martin and the Beggar; St. Martin the Bishop; St. Martin of Tours; tetramorph; Pavao Vojković; parish church; Varaždinske Toplice; contemporary religious art. 